DOI 10.14746/ssp.2020.1.10

\title{
Grzegorz PIWNICKI
}

Uniwersytet Gdański

ORCID: 0000-0001-5489-4028

\section{Anomia jako kulturowy stan społeczeństwa polskiego w czasach nowożytnych praprzyczyną dystopii integracji z Unią Europejską}

Motto: Ojczyzna jest to wielki - zbiorowy - obowiązek

(C. K. Norwid, s. 343)

Streszczenie: $\mathrm{W}$ artykule zaprezentowano analizę problemu dotyczącego integracji z Unią Europejską przez pryzmat uwarunkowań historycznych, które mają istotny wpływ na włączenie Polski do obszaru centrum Europy. Założono, że jest to wynikiem podziału ekonomicznego na Europę Zachodnią (kapitalistyczną) i Wschodnią (rolniczą) w XVI wieku. To implikowało odmienność kulturową tych obszarów istniejącą do czasów obecnych w układzie centro-peryferyjnym. Podział ten wygenerowały, stosunki feudalne do II połowy XIX wieku na Wschodzie i kapitalistyczne na Zachodzie. Brak nowoczesnego państwa z jego strukturami administracyjnymi, silnej władzy i armii, mieszczaństwa (burżuazji) oraz nowych prądów religijnych (protestantyzmu) złożyły się na swoistego rodzaju rozwój anomii i dystopii w Polsce. Drugim wątkiem analizy naukowej było zagadnienie zaniechania integracji z Unią Europejską po 2015 roku. W wyniku tego zaistniała możliwość znalezienia się Polski poza centrum cywilizacyjnym Europy Zachodniej. Wizja Polski, jako peryferia Europy jest swoistą anomią i dystopią dla społeczeństwa i państwa.

Słowa kluczowe: anomia, dystopia, centrum, peryferia, integracja europejska, Unia Europejska

\section{Wprowadzenie}

Wartykule osnowę analizy naukowej zaprezentowano przez pryzmat pojęć anomii i dystopii. Pierwszy z tych stanów, w którym jednostka pozbawiona jest moralnego wsparcia $\mathrm{w}$ grupie przestaje być zdolna do normalnego życia, a społeczeństwo (polskie) niezdolne do sprawowania nad nią opieki i kontroli, staje u progu rozkładu - zdefiniował to Emil 
Durkheim (Skarżyńska, 2002, s. 294). Natomiast drugi dystopia to stan odwrotny od utopii, czyli antyutopia lub kakotomia. Tam znajdziemy się w wizji zdegradowanego świata, będącego zaprzeczeniem prawdziwego demokratycznego społeczeństwa. Jest to wersja teorii alienacji istoty człowieka. Zapisany w temacie artykułu ład kulturowy to porządek, w którym jedność i wielkość powinny pozostawać ze sobą w symbiozie. Aktualnie w Polsce problematykę tę podnosi się pod sztandarami tożsamości, nacjonalizmu i różnicy (rozwarstwienia) społeczeństwa na wrogie obozy. To determinuje bardzo groźny efekt, w postaci dezintegracji z Unią Europejską. A Unia jest jedyną ostoją twardej perspektywy istnienia, jako podmiotu politycznego polskiego społeczeństwa w nadchodzącej przyszłości XXI wie$\mathrm{ku}$. W kolejnej odsłonie zaprezentowano wizję teorii J. Wallersteina i jej wpływ na peryferyjność gospodarczą Polski, przez pryzmat przeobrażeń w Europie od XVI wieku do czasów obecnych. Skutkiem tego jest pozycja naszego państwa w Europie. Zwłaszcza po likwidacji polskiego przemysłu w programie prywatyzacji po 1990 roku. Kolejny kontekst prezentowany w artykule to pozycja Unii Europejskiej w świecie, jako potencjalnego trzeciego mocarstwa ekonomicznego, militarnego i kulturowego w niedalekiej przyszłości. A zatem głównym wątkiem opracowania jest dezintegracja Polski z Unią oraz kontekst zagrażający dla niej z perspektywy pozostania poza Zjednoczoną Europą. Zaprezentowano to poprzez pięć odsłon: 1) współczesne relacje państwo - Kościół katolicki; 2) skutki toksycznego patriotyzmu; 3) nienawiść w Polsce - zagrożenie dla państw. Anomia; 4) spór o integrację z Unią Europejską w naszym kraju. Dystopia; 5) Unia Europejska wobec niepraworządności. Celem prezentowanego artykułu jest analiza aktualnego poziomu dezintegracji Polski z Unią. Aby przybliżyć tą problematykę autor postawił następującą hipotezę ogólną: aktualnie istnieje wielkie zagrożenie wyjścia Polski ze struktur Unii Europejskiej, może to być exitpol lub polexit. W związku z badaniami postawił pytania badawcze: 1. Jakie jest aktualnie miejsce Polski w ładzie europejskim? 2. Czy Unia Europejska może być światowym mocarstwem? 3. Jakie są obecnie największe zagrożenia w Polsce z integracją europejską? 4. Czy Unia jest najważniejszym dla Polski gwarantem jej ekonomicznego, politycznego i militarnego bytu? W analizie badanego problemu naukowego posłużono się następującymi metodami: 1) podejściem idiograficznym w deskrypcji zjawisk jednostkowych oraz monotetyczną predykcją ukierunkowaną na wykrywaniu uniwersalnych reguł rządzących konkretnymi zjawiskami; 2) wykorzystano heurystykę do odkrywania nowych prawd poprzez postawienie hipotezy oraz pytań badawczych. 


\section{O definiowaniu anomii i dystopii}

Prekursorem studiów nad anomią w nauce jest Emil Durkheim. Uważał, że rozwój systemu kapitalistycznego prowadził do zerwania więzi społecznych charakterystycznych dla społeczności tradycyjnych, ale jednocześnie nie wytwarzał nowych instytucji mogących skutecznie pełnić dawne funkcje: i religii, i organizacji. Taki stan, w którym ,jednostka jest pozbawiona moralnego oparcia $\mathrm{w}$ grupie przestaje być zdolna do normalnego życia, a społeczeństwo niezdolne do sprawowania nad nią moralnej opieki i kontroli staje się zaczynem rozkładu" nazwał Durkheim anomią. W warunkach społecznej anomii jednostek zaczyna brakować regulacji, co jest dla nich źródłem cierpienia, ludzie przestają wiedzieć, co jest możliwe, a co niemożliwe; co sprawiedliwe, a co niesprawiedliwe; jakie rewindykacje i nadzieje są uprawnione, jakie zaś idą zbyt daleko (Durkheim, 1961). W konsekwencji Durkheima anomia stanowi przede wszystkim charakterystykę struktury społecznej i kulturowej. Problematyką anomii zajmował się też Robert King Merton. Jego analizy wyrastają nade wszystko ze społecznej sytuacji Stanów Zjednoczonych na przełomie lat dwudziestych i trzydziestych XX wieku. Definiuję anomię, jako „załamanie zdarzające się w strukturze kulturowej, występujące zwłaszcza wtedy, kiedy istnieje silna rozbieżność między normami i celami kulturowymi a społecznie ustrukturowanymi możliwościami działania członków grupy zgodnie z tymi normami” (Merton, 1982, s. 189-202). W latach pięćdziesiątych XX wieku dokonała się zmiana systemowa tego pojęcia. Anomia staje się zjawiskiem psychologicznym. Pierwszymi naukowcami, którzy dokonali tego zwrotu byli Robert K. MacIver i Dawid Riesman. Według MacIvera ,,anomia oznacza stan świadomości człowieka wykorzenionego moralnie, człowieka, który zamiast norm posiada już tylko chaotyczne popędy, który został pozbawiony poczucia ciągłości, wspólnoty, zobowiązania. Człowiek anomiczny stał się sterylny duchowo, reaguje wyłącznie na samego siebie, przed nikim nie jest odpowiedzialny" (MacIver, 1950, s. 84-87). Wspomniani wyżej klasycy upatrywali przyczyn anomii w dezorganizacji struktury społecznej spowodowanej destrukcją i przemianami postaw, tejże struktury. Opisywane zjawiska lokowali w czasach rozkwitu lub kryzysu demokracji (Skarżyńska, 2002, s. 293-297). Warto w tym miejscu wrócić do R. K. Mertona, który wyróżnił pięć typów adopcji społecznej, którymi może iść jednostka dotknięta anomią, są to: 1) konformizm; 2) innowacja; 3) rytualizm; 4) wycofanie; 5) bunt. Możemy je scharakteryzować w następujący sposób: Ad. 1. Kon- 
formizm oznacza stosowanie przez jednostkę jedynie środków kulturowo i społecznie usankcjonowanych, legalnych - postawa ta dominuje wśród tych grup społecznych, które dysponują przynajmniej niektórymi rzeczywistymi środkami do realizacji celów. Ad. 2. Innowacja to akceptowanie stawianych przez społeczeństwo celów przy jednoczesnym odrzuceniu dominującego rozumienia legalności środków. Postawa taka prowadzi często do zachowań przestępczych, przyjmują ją najczęściej osoby, które mają nikłe szanse realizacji celów społecznych w inny sposób. Ad. 3. Rytualizm polega na akceptacji przez jednostkę tylko środków legalnych przy świadomości, że osiągnięcie wyższej pozycji społecznej nie jest za ich pomocą możliwe. Wiąże się więc z aspiracji - rezygnacja taka nie jest jednak źródłem frustracji, normatywna akceptowalność środków traktowana jest bowiem jako wartość samoistna. Ad. 4. Wycofanie się polega na rezygnacji i z używania środków uznawanych za właściwe, i z osiągania celów stawianych przez społeczeństwo - jest to, więc postawa rezygnacyjna, postawa nieuczestniczenia w działaniach społecznych. Ad. 5. Bunt to odrzucenie celów, które społeczeństwo uznaje za właściwe i postawienie sobie przez jednostkę celów, które uznaje za wyższe. Bunt to zazwyczaj postawa aktywistyczna, dążenie do zmiany panujących stosunków społecznych (ENCENC).

Dystopia. Autorstwo pojęcia dystopia przypisuje się Johnowi Stuartowi Millowi (1806-1873) - angielskiemu filozofowi, politologowi i ekonomiście, który wygłaszając 12 marca 1868 roku w Izbie Gmin parlamentu angielskiego mowę skierowaną przeciwko opozycji, powiedział o swoich przeciwnikach politycznych: „Zapewne zbytnim pochlebstwem jest nazywanie ich utopistami. Powinno się ich raczej nazywać dys-topistami albo kako-topistami. To, co powszechnie zwie się Utopią, jest bowiem czymś zbyt dobrym, aby być możliwym w praktyce; lecz to, czego oni zdają się pragnąć, jest zbyt złe, aby znaleźć praktyczne zastosowanie". Kontekst mowy pozwala przypuszczać, że Mill miał na myśli miejsce, gdzie rzeczy mają się źle, rodzaj społecznego Zło-bytu, a nie prostą odwrotność utopii, gdyż grecki przedrostek dys- albo disznaczy chory, zły. Biorąc pod uwagę intencję Milla, można dokonać translacji tego terminu jako „utopii negatywnej”. Dystopia, podobnie jak utopia, stanowi formę deskrypcji fikcyjnego społeczeństwa, umiejscowionego przeważnie w przyszłości. Stosuje się do tego także pojęcia pokrewne, jak cacotopia, kakotopia (gr. caco - zły), antyutopia, utopia negatywna, czarna utopia. Społeczeństwo dystopijne jest zamknięte, hermetyczne, ale wobec świata zewnętrznego żywi lęk, wrogość lub wstręt, 
a często wręcz znajduje się z nim w stanie permamentnej wojny (nie zawsze militarnej). Państwo jest rządzone przez klasę wyższą - elitę społeczną, deklarującą tylko formalnie pewne idee demokratyczne lub jawnie autorytarne. Cechą dystopijną staje się taka forma despotyzmu, gdy rządy są społeczeństwu zdolnemu do samostanowienia narzucone siłą, a w szczególności, gdy rząd zgłasza pretensje do pewnych demokratycznych zasad, tak jak np. w Roku 1984, G. Orwella (nowomowa, ministerstwo prawdy itd.) (Orwell, 1988, s. 144). Propaganda państwa i system edukacji przymuszają obywateli do wielbienia państwa i jego rządu, usiłują upewniać w przeświadczeniu, że życie w takim totalitarnym reżimie jest dobre i prawe. W takim państwie stosuje się inwigilację, prowokacje, represje, estabilishment utrzymuje przeświadczenie, że tworzy świat najlepszy z możliwych, a wszystkie problemy są wynikiem knowania wrogów. Na czele dystopijnego państwa stoi głowa państwa, którą członkowie społeczeństwa wielbią fanatycznie, jak np. Wielki Brat w Roku 1984. Kultowi temu sprzyja nieobecność, marginalizacja lub kolaboracja wykształconej klasy średniej np. nauczycieli, naukowców itd., którzy potencjalnie mogliby krytykować ten stan w państwie. Standard życia w klasie średniej i niższej jest generalnie znacząco niższy od typowego dla tej warstwy. $Z$ reguły społeczeństwo dystopijne powstaje w wyniku radykalnego przerwania ciągłości tradycji społeczno-kulturowej, jako forma apoteozy Nowego Początku. Powszednie głoszony jest pogląd, że tamten (stary) styl życia jest archaiczny i pozbawiony sensu (Głażewski, 2010, s. 30-51). W początkach XXI wieku dużo częściej mamy do czynienia z pojęciem dystopii. Miejsce przemawiających do wyobraźni opisów możliwego raju na ziemi, tak charakterystycznych dla literatury utopijnej od czasów Platona, zajmują coraz częściej wizje przyszłości obdartej z jakichkolwiek marzeń o lepszym jutrze. Thomas Hobbes zauważył, że głównymi i bezsprzecznie nadrzędnymi motywami ludzkich działań są dwa uczucia: strach i nadzieja. Utopie postrzegać można jako projekty zrodzone $\mathrm{z}$ doświadczanego bezpośrednio strachu przed widocznie wrogą rzeczywistością społeczno-polityczną oraz skrytej nadziei, że strach ten jest wyłącznie pochodną niewłaściwych instytucji życia wspólnotowego, a więc jako źródło jest nienaturalne i nieracjonalne. Dystopie przeciwnie, wyrastają z rozbudzonych i jawnych nadziei kreowanych przez rzeczywistość oferującą względny dobrobyt i samozadowolenie - oraz utajonego strachu, że nadzieje te wcześniej czy później legną w gruzach, bo i one opierają się na nietrwałych fundamentach (Barwicka-Tylek, Eckhard, Guzy, 2017). 


\section{Wizja teorii Imanuela Wallersteina i jej wpływ na historyczną spuściznę kapitalizmu peryferyjnego w Polsce}

Problem ten przedstawił Imanuel Wallerstein w swojej pracy pt. Analiza systemów - światów. Wprowadzenie (Wallerstein, 2007). Po pierwsze, praca ta pozwala na reinterpretację historii Polski i całego regionu Europy Wschodniej. Po drugie, pozwala zrozumieć problemy na jakie natrafiają kolejne projekty modernizacji gospodarczej i społecznej realizowane na tym obszarze od XIX wieku. Dotyczy to także aktualnego procesu integracji europejskiej.

Klasycznych przykładów sytuacji kraju peryferyjnego dostarcza nowożytna historia Polski. W swoim dziele Wallerstein, sporo miejsca poświęca ewolucji formacji kapitalizmu peryferyjnego w Europie Wschodniej. Amerykański socjolog oparł się na analizach polskiego historyka Mariana Małowista (Małowist, 1973)1. Wschodnia część kontynentu stała się najstarszą i najbliższą częścią peryferii systemu kapitalistycznego. Historycznie rzecz biorąc, mechanizmy polaryzacji określające charakter kapitalistycznej akumulacji w skali światowej kształtowały się najpierw na dwóch granicach: zewnętrznej (atlantyckiej), biegnącej między Europą a Nowym Światem, oraz wewnętrznej (wzdłuż Łaby), biegnącej między wschodem a zachodem Europy. Polski złoty wiek, który w mitologii historycznej odgrywa rolę okresu najwspanialszego rozkwitu, w rzeczywistości był przyczyną późniejszych kłopotów, z których Polska nie może się wydostać do dzisiaj. Jeszcze w końcu wieku czternastego wschód i zachód Europy zasadniczo się od siebie nie różniły. Przebiegający wzdłuż Łaby podział starego kontynentu uformował się dopiero wraz z rozwojem wczesnych struktur produkcji kapitalistycznej, a więc $\mathrm{w}$ okresie, który Wallerstein nazywa długim wiekiem szesnastym (lata 1450-1620/40). To właśnie wtedy pojawiła się specjalizacja $\mathrm{w}$ produkcji na poszczególnych obszarach, nierówności w wymianie między nimi oraz odmienne ekonomiczne formacje społeczeństwa. Różnice między Wschodem a Zachodem nie były, zatem dziedzictwem odległej przeszłości, ale konsekwencją rozwoju nowego systemu

${ }^{1}$ Marian Małowist (1909-1988), historyk dziejów gospodarczych. Studiował na Uniwersytecie Warszawskim (uczeń prof. M. Handelsmana). Wprowadzenie w problematykę gospodarczą zawdzięczał znawcy ekonomiki nowożytnej, historykowi szwedzkiemu Eli Heckscherowi, u którego pracował przed II wojną. Badał handel bałtycki w XVI wieku (doktorat 1934), habilitował się w 1946 r. na UW. Badał m.in. miejsce Europy Środkowo-Wschodniej w systemie gospodarczym Europy oraz mechanizm gospodarczy Europy u schyłku średniowiecza i w początkach ery nowożytnej. 
historycznego. Przewaga Zachodu rosła wprost proporcjonalnie do wzrostu intensywności jego powiązań handlowych z krajami na wschód od Łaby. Ulokowane na północnym zachodzie Europy ośrodki kapitalizmu rozwijały się nie tylko dzięki czynnikom wewnętrznym, takim jak intensywny (oparty na wzroście wydajności) i kapitałochłonny charakter produkcji, rozwój miast, słabość szlachty, silne państwo, stosunkowo duża gęstość zaludnienia. Znaczną rolę odegrało także ,przyjazne otoczenie” umożliwiające przechwytywanie nadwyżek handlowych. Złoto i srebro zrabowane w Ameryce i przejęte od słabnącej Hiszpanii oraz tanie zboże i bydło z Europy Wschodniej stanowiły warunek pierwotnej akumulacji kapitalistycznej. Zachód wypchnął na zewnątrz mniej rentowne i bardziej pracochłonne dziedziny produkcji, dzięki czemu sam mógł skoncentrować się na tym, co przynosiło większe korzyści. To, co dla Niderlandów, Anglii, północnych regionów Francji i Włoch było błogosławieństwem, dla Rzeczpospolitej i Węgier stało się prawdziwym przekleństwem historii (Sosnowska, 2004). Formowanie się nowoczesnego mieszczaństwa na Zachodzie towarzyszyło wtórne poddaństwo chłopów na Wschodzie. Proces odbierania chłopom wolności osobistej oraz rozwój niewolnictwa w Nowym Święcie postępowały wraz z tworzeniem się struktur produkcji kapitalistycznej i zacieśnianiem stosunków handlowych z centrum kapitalistycznej gospodarki-świata. Obydwa te zjawiska stanowiły najważniejszy aspekt społecznej treści formacji kapitalizmu peryferyjnego. Zapewniały reprodukcję jego największego ,atutu” w ramach systemowego podziału pracy, czyli darmową, siłę roboczą. To właśnie ona sprawiała, że gospodarka oparta na wielkiej własności ziemskiej i ekstensywnej uprawie roli była opłacalna. Jak pisał Witold Kula, ,jeśli mimo niskiej wydajności pracy i mimo obciążenia kosztami długiego transportu morskiego produkty owych „kolonii” (Europy Wschodniej z jednej, a kolonii amerykańskich z drugiej strony) zwyciężają i znajdują zbyt na rynkach anglo-holenderskich, to dziać się tak może jedynie dzięki niższemu opłacaniu siły roboczej, taniej gdyż niewolnej: w Europie - poddańczej, w Ameryce - niewolniczej” (Kula, 1983, s. 187). Z drugiej strony wyzysk niewolnej siły roboczej zapewniał Zachodowi warunki do umacniania swej przewagi nad peryferiami. Produkty wschodnioeuropejskich folwarków i latynoskich latyfundiów nie znajdowały przecież zbytu na lokalnych rynkach. Słabe miasta, biedne mieszczaństwo i funkcjonujący poza rynkiem towarowo-pieniężnym chłopi (lub niewolnicy) nie byli w stanie skonsumować wytwarzanych bogactw. Aby cykl kapitalistycznej akumulacji mógł się domknąć, a kapitał wytworzony w gospodarce zrealizować (czyli zostać 
wymieniony na pieniądze), trzeba było sprzedać produkty pracy społecznej na zewnątrz. Eksport stawał się sprawą życia lub śmierci, bo tylko on mógł zapewnić reprodukcję kapitału, a w konsekwencji także utrzymanie klasowej dominacji jego dysponentów. W ten sposób kształtowało się uzależnienie peryferyjnej produkcji od rynków centralnych, będących jej odbiorcami. Zachodni kupcy nie tylko kontrolowali szlaki komunikacyjne i ważne ośrodki handlowe (przykładem może być Gdańsk) na Wschodzie. Uzyskali także wielki wpływ na ceny i kwoty produkcji. Wymiana, w której produkty rolne sprzedawano w zamian za drogie towary luksusowe nigdy nie była symetryczna. Mogła się opłacać tylko stronie, która kupowała tanio, a sprzedawała drogo. Po stronie drugiej powodował stały deficyt gotówki, który z kolei sprzyjał zaciąganiu długów u odbiorców (w formie zadatków na kolejne zbiory). W takiej sytuacji kupcy z centrum mogli decydować także o cenach zadatkowanych zbóż, natomiast obszarnicy z peryferii wpadali w prawdziwą pętlę zadłużenia. Według Wallersteina rolniczy i wiejski charakter wschodu Europy stał się rewersem uprzemysłowienia i urbanizacji na Zachodzie, nie tylko jego konsekwencją, ale też warunkiem koniecznym. Uważa On, że włączenie Europy Wschodniej i Ameryki hiszpańskiej do europejskiej gospodarki-świata w szesnastym wieku nie tylko dostarczyło kapitału (poprzez łupieżczy margines zysku), ale także pozwoliło części siły roboczej w centrum na specjalizację w innych dziedzinach. [...] Trendem obowiązującym w centrum było dążenie do różnorodności i specjalizacji, podczas gdy w peryferiach trendem stała się monokultura. Analiza procesów peryferyzacji, którym w szesnastym wieku uległy Ameryka Łacińska oraz Europa Wschodnia jest ważna nie tylko ze względu na to, że rewolucjonizuje nasze wyobrażenie o przeszłości. Ta rewizja historyczna ma bardzo aktualny sens. Doświadczenia historyczne obszarów zepchniętych na pozycje podrzędne $\mathrm{w}$ globalnym podziale pracy pozwalają zrozumieć ograniczenia, na jakie natrafiają obecne próby modernizacji peryferii (i półperyferii). Skoro niedorozwój nie jest wynikiem zapóźnienia w podążaniu za ulokowaną na euroatlantyckim centrum awangardą światowego rozwoju, ale wynikiem pewnej, nierównoprawnej, postaci integracji z tą awangardą $\mathrm{w}$ ramach jednego systemu, to wysiłki nadrobienia dystansu czy dogonienia Zachodu muszą być skazane na niepowodzenie. W ramach podziału na centrum i peryferie, narzuconego przez kapitalistyczne, korporacyjne globalne prawo wartości, nie da się dogonić najbogatszych. Wyjście z peryferii jest oczywiście możliwe. Szansa ta dotyczy przede wszystkim krajów półperyferyjnych. Może się jednak dokonać tylko na drodze zakwestionowania logiki nierównomiernej wymiany oraz przezwyciężenia ukła- 
dów sił klasowych charakterystycznych dla zależnej formacji społecznej. Właśnie niemożliwość sprostania tym wymaganiom stała się przyczyną trwałości peryferyjnego lub półperyferyjnego statusu Europy Wschodniej. Przebieg restauracji kapitalizmu w Europie Wschodniej po roku 1989 zdaje się potwierdzać trwałość mechanizmów opisywanych przez Wallersteina. Wiele wskazuje na to, że obserwujemy powrót Polski na miejsce, które zajmowała ona w międzynarodowym podziale pracy od szesnastego wieku aż do roku 1945. Neoliberalna globalizacja korporacyjna zaostrzyła ten proces i nawet wejście naszego kraju do Unii Europejskiej nie zmieniło tendencji do restauracji półperyferyjnego statusu Polski². Wpłynęło to negatywnie na sam kształt projektu europejskiego. Obecna sytuacja różni się pod wieloma względami od tej, która towarzyszyła wchodzeniu do struktur europejskich półperyferyjnych krajów takich jak Hiszpania, Grecja i Portugalia. W latach siedemdziesiątych i osiemdziesiątych minionego wieku socjalna zawartość projektu europejskiego nie była jeszcze tak zdecydowanie kontestowana (państwo opiekuńcze), a przyczyniały się do tego zarówno siły zorganizowanego ruchu robotniczego, jak i zagrożenie ze strony radzieckiego mocarstwa. Dziś obydwie te okoliczności nie przeszkadzają restrukturyzacji projektu europejskiego. Wewnętrzne pęknięcie, które określa obecnie jego charakter, związane jest po pierwsze, z presją neoliberalizmu w polityce poszczególnych państw członkowskich „starej” Unii, po drugie zaś, ze wzmocnieniem presji, które dokonało się za sprawą wejścia do UE państw postkomunistycznych. Dominujące sektory zachodnioeuropejskiego kapitału wykorzystują podziały wewnątrz Unii, odnosząc korzy-

2 Jest to wynikiem fatalnego w skutkach przyjęcia gospodarczego modelu liberalnego opartego na sprywatyzowaniu polskiej gospodarki, która okazała się wyprzedażą całego przemysłu setek zakładów, likwidacji instytutów naukowo-badawczych. W wyniku tego Polska stała się państwem rolniczym, zależnym od Zachodu. Błędu tego nie popełniła Czechosłowacja, która modernizowała swój przemysł i rozbudowała go, np. Zakłady Samochodowe Skoda można porównac z polską firmą FSO - Żerań. Przez ponad 20 lat w każdym polskim budżecie rocznym zapisywano pozycje - wpływy z prywatyzacji. Drugą przyczyną takiego stanu rzeczy jest polska polityka integracji z Unią Europejską. Przez 15 lat nie było wizji zacieśnienia jej z największymi państwami i usadowienia się Polski w twardym rdzeniu Unii, tym samym o decydowaniu i kierunku rozwoju społeczno-ekonomicznego. Nasze państwo jest bierne i oczekuje tylko pomocy z funduszy unijnych, to droga do nikąd. Przykładem fatalnej polityki jest wysyłanie przez partie polityczne posłów do parlamentu europejskiego (ignorantów) nieznających języków obcych i funkcjonowania instytucji Unii Europejskiej. To synekury dla swoich działaczy. Fatalnym tego przykładem jest wybór polskich europosłów do Unii Europejskiej w wyborach 2019 roku. Polska tylko na tym traci. Jest to kierunek peryferii dla naszego kraju. 
ści z różnic w poziomie rozwoju ekonomicznego i wartości siły roboczej. Wysokie płace, standardy socjalne i PKB na Zachodzie oraz niskie płace, „liberalne” standardy i niskie PKB na Wschodzie pozwalają zwiększać zyski na drodze delokalizacji produkcji na wschód, a także szantażu wywieranego na zachodnich pracownikach (Starnowski, Wielgosz, s. I-XXXIV). Przykładem tego, jak to działa, niech będzie porównanie wydajności i ceny siły robotnej w Polsce i w „starej Unii”. O ile wydajność w Polsce osiągnęła już poziom 50 procent wydajności na Zachodzie, to płace utrzymują się na poziomie 30 procent płac zachodnich. Powstała w ten sposób luka jest źródłem zysków dla kapitału lokalnego i unijnego, a także głównym źródłem atrakcyjności Polski dla zagranicznych inwestorów. Wszystko to, sprzyja utrwalaniu wewnątrzunijnej nierówności w systemie płac ${ }^{3}$. Nowe państwa Unii ciążą ku powiązaniom z USA i jako takie pełnią rolę konia trojańskiego Stanów Zjednoczonych, które z kolei zdecydowanie sprzeciwiają się europeizacji unijnej polityki zagranicznej i obronnej. Według USA zjednoczona Unia Europejska zagrażałaby interesom globalnym tego państwa. Teoria systemu światowego szybko pokazała, że jest niewystarczająca dla współczesnej globalizacji. Zainteresowanie teoretyków przesunęło się od ekonomii do kultury. Co oznacza, że Polska samodzielnie, w systemie globalizacji nie może funkcjonować. Jedyną jej przyszłością jest wejście do pełnej integracji z UE (Sztompka, 2003, s. 589).

\section{Wizja Unii Europejskiej, jako mocarstwa światowego}

Stany Zjednoczone Unię Europejską postrzegają, jako swojego przeciwnika ekonomicznego. Przykładem jest spotkanie prezydenta Trumpa na szczycie NATO (2018 r.), gdzie stwierdził, że Unia Europejska to największy wróg USA. Natomiast podczas wizyty prezydenta Trumpa

${ }^{3}$ Ursula von der Leyen 15 stycznia 2020 r. zaproponowała wprowadzenie na poziomie unijnym zasady na jakich ustala się płacę minimalną. Poziom tego świadczenia ma stanowić 60 proc. średniej płacy w państwach UE. Hiszpański „El Pars” poinformował, że jeszcze w tym miesiącu (styczeń 2020) KE przedstawi państwom członkowskim projekt tzw. europejskiej płacy minimalnej. Komisja ma zobowiązać rządy wszystkich państw unijnych do zagwarantowania tej kwoty w krajowych przepisach. Poziom płacy miałby być różny w każdym państwie, ale nie mniejszy niż 60 proc. przeciętnego wynagrodzenia w tym kraju. Dodatkowo Komisja planuje utworzenie europejskiego ubezpieczenia społecznego. Aktualnie w Polsce minimalna płaca wynosi nieco ponad 45 proc. przeciętnego wynagrodzenia. 
we Francji, na spotkaniu z prezydentem Macronem stwierdził, że Francja powinna wystąpić z Unii Europejskiej, a Stany Zjednoczone podpiszą z nią lepsze warunki współpracy finansowej. Starają się o to, aby Unia nie stała się Federacją Europejską z własną armią, rządem, konstytucją i systemem finansowo-gospodarczym opartym na euro. Wynika to $\mathrm{z}$ tego, że Zjednoczona Unia stałaby się mocarstwem światowym, które mogłoby konkurować z USA i Chinami. Zjednoczona Europa liczyłaby ponad pół miliarda obywateli, co czyniłoby ją trzecim z kolei najludniejszym organizmem politycznym w świecie - po Chinach, Indiach i o 200 milionów większym niż Stany Zjednoczone. W 2016 roku PKB państw Unii Europejskiej wyniosło ponad 16,5 bln dolarów, bogactwo nie jest do końca równo rozprowadzone. Jeśli przyjrzymy się mu pod kątem siły nabywczej, a więc uwzględniając ceny towarów, okaże się, że regiony wschodnie są zdecydowanie biedniejsze od środkowych i północnych. Jeżeli Unia chce aspirować o roli światowego lidera, obronić oświeceniowe wartości, to nie może pominąć obronności. Mimo że zjednoczona Europa nie prowadzi na razie spójnej polityki militarnej - co oznacza, że trudno traktować budżety zbrojeniowe poszczególnych krajów jako jeden wspólny - możemy przyjąć, że nie powinniśmy mieć kompleksów w stosunku do światowych mocarstw militarnych i ekonomicznych. Jak wskazują dane SIPRI, pod względem wydatków na wojskowość ustępuje ona Stanom Zjednoczonym, ale nieznacznie wyprzedza Chiny i trzykrotnie przewyższa Federację Rosyjską. Problemem Unii jest to, że wkrótce nie będzie, komu zasilić armii, fabryk, ani uczelni. Pomimo ekonomicznej potęgi społeczeństwo Unii starzeje się. Osób w wieku 30-59 lat jest o jedną czwartą więcej niż tych przed trzydziestym rokiem życia. Najwięcej mieszkańców zjednoczonej Europy jest w wieku średnim, a dzieci jest mało. Jeśli tak dalej pójdzie, coraz mniejsza część populacji będzie w stanie pracować i całe wspaniałe dokonania mogą zniknąć. Od poważnych problemów uratować ją mogą roboty, albo imigranci (Kopeć, 2018, s. 14). Polska w tych realiach powinna jasno określić swoje miejsce we współczesnym świecie. Jeżeli wybierze aktywny udział w UE będzie współtworzyła Federację Europejską, możliwie najszybciej przyjmie euro oraz znajdzie się w twardym jądrze Wspólnoty, mieć będzie wpływ na podejmowanie tam strategicznych decyzji oraz szansę wydobycia się z peryferii. Jeżeli wybierze alians transatlantycki z USA nie wyjdzie z peryferii. Podsumowując rolę i znaczenie Unii Europejskiej w świecie, można to uogólnić i przedstawić jej dokonania dla światowego ładu: 
1) Unia Europejska prowadzi, wspiera rozmowy pokojowe na całym świecie w celu rozwiązywania konfliktów;

2) podejmuje na całym świecie działania na rzecz demokracji i rządów prawa. Prawa człowieka są szczególnie ważnym aspektem w relacjach z innymi państwami;

3) na arenie międzynarodowej działa na rzecz zwalczania terroryzmu, przestępczości zorganizowanej i nielegalnej imigracji;

4) jest liderem w światowej walce ze zmianą klimatu;

5) Unia i jej państwa członkowskie razem są największym na świecie dawcą pomocy na rzecz rozwoju. Ten wkład oznacza realną pomoc dla milionów ludzi na całym świecie;

6) wspiera rozwój również poprzez handel, otwierając w tym celu swoje rynki na produkty z krajów rozwijających się, a także zachęcając te kraje do zwiększania wzajemnej wymiany handlowej;

7) jej państwa członkowskie razem są największym na świecie dawcą pomocy humanitarnej. Ratują ludzkie życie, udzielając pomocy ofiarom katastrof, uchodźcom i innym potrzebującym ${ }^{4}$.

\section{Problemy ladu kulturowego w Polsce początku XXI wieku. Zagrożenia dla integracji z Unią Europejską}

\subsection{Współczesne relacje państwo - Kościół katolicki}

Kwestią aktualnych stosunków państwa i Kościoła katolickiego w Polsce analizował i opisał dominikanin Tomasz Dostatni. Stwierdził, że relacje te determinują ludzie sprawujący władzę na różnych szczeblach. Wywodzą się oni z jednej partii (PiS) i kościoła. Dostrzega w tych stosunkach „niepokojące zjawiska”. W tym kontekście zwraca uwagę na cztery ważne zasady:

1. Zasadę pomocniczości. Według niej, wypracowanej przez nauczanie kościoła „Społeczność wyższego rzędu Nie powinna ingerować w wewnętrzne sprawy społeczności niższego rzędu [...], lecz raczej powinna wspierać ją" - dla dobra wspólnego. Dzisiaj władza państwowa próbuje tak zmieniać prawo, żeby różne przestrzenie życia pozbawiać

\footnotetext{
${ }^{4}$ Informacje o UE we wszystkich 24 językach urzędowych; www.europa.eu.
} 
podmiotowości. Jest to widoczny zwrot w stronę państwa autorytarnego. Tracimy państwo obywatelskie na rzecz silnej ingerencji państwa w życie obywateli. Etatyzm, ale też brak pluralizmu ideowego muszą prowadzić do dominacji jednej partii. Niszczony jest dorobek wielu lat, kiedy budowano społeczeństwo obywatelskie, gdzie podmiotem jest człowiek aktywny i kreatywny, wspierane zaś jest podporządkowanie obywateli kruchej większości, która uważa siebie za reprezentanta „suwerena".

2. Zasadę solidarności. W czasie pielgrzymki w 1987 roku Jan Paweł II mówił w Gdańsku do ludzi pracy - „»Jeden drugiego brzemiona noście« - to zwięzłe zdanie Apostoła jest inspiracją dla międzyludzkiej i społecznej solidarności. Solidarność - to znaczy: jeden i drugi, a skoro brzemię, to brzemię niesione razem, we wspólnocie. A więc nigdy: jeden przeciwko drugiemu. Jedni przeciw drugim. I nigdy »brzemię« dźwigane przez człowieka samotnie. Bez pomocy drugich". Źle jest, ,gdy mówi się: naprzód »walka« [...] - bardzo łatwo drugi czy drudzy pozostają na »polu społecznym « przede wszystkim jako wrogowie. Jako ci, których trzeba zwalczyć, których trzeba zniszczyć". Dziś powiedziałbym o tym sposobie myślenia: etyka solidarności. Teraz problem jest jeden - uchodźcy. Papież Franciszek, odwołując się wprost do Ewangelii, wręcz krzyczy: zajmijcie się tymi nieszczęśliwymi ludźmi skutecznie! Przed jego wizytą w Polsce wydawało się, że po stronie władz jest dobra wola dla inicjatywy tzw. korytarzy humanitarnych. Po wyjeździe papieża, przewodniczący Episkopatu Polski abp Stanisław Gądecki konstatował, że po stronie rządowej nie ma woli rozwiązania tego problemu. Biskupom nie wypada powiedzieć, że katolicy w Polsce zostali oszukani. Polityka rozumiana wąsko i partyjnie bierze górę nad zasadą solidarności, do której owi politycy chętnie się odwołują. Nieliczenie się z drugim człowiekiem pozbawionym domu w wyniku wojny, głodu czy chcącym poprawić swoje warunki życiowe musi prowadzić do budowania społeczeństwa na zasadzie egoizmu, bez dobrej perspektywy na przyszłość.

3. Braku debaty publicznej. Instytucje państwa, które są upoważnione do zglaszania ustaw w Sejmie, nie podejmują zwyczajowych konsultacji z podmiotami społecznymi. Jednym z nich jest kościół. Dobrym zwyczajem było przedstawianie do konsultacji stronie kościelnej, tak jak wielu innym instytucjom, projektów ustaw. Dziś polski ustawodawca chętnie powołuje się na chrześcijaństwo, ale zupełnie nie dba o to, by upoważnione do tego organy Episkopatu wyrazily choćby najmniejszą opinię. 
Strona kościelna jest często stawiana przed faktami dokonanymi. Może co najwyżej milczeć.

4. Rezygnacji z mediacyjnej roli kościoła. Spór wokół administracyjnego poszerzenia Opola pokazał, że nawet w najbardziej ostrej fazie konfliktu, gdy głodówka stała się już zagrożeniem dla życia uczestników, miejscowy biskup nie był, ujmując rzecz najdelikatniej, traktowany jako poważny partner społeczny. Szef MSW, pani premier, a także prezydent RP nie widzieli potrzeby spotkania lub podejmowali działania pozorne. Tymczasem rolę mediacyjną kościół odgrywał w polskiej historii wielokrotnie.

Wymienione zasady to przestrzeń nieuniknionego konfliktu kościoła z władzą. Wydaje się, że misja i rola Kościoła nie są przez nią rozumiane. Cele polityczne to nie to samo, co misja ewangeliczna i religijna - a także moralna - chrześcijaństwa. Kościół ma prawo patrzeć na ręce każdej władzy i wypowiadać swoje zdanie jak każdy obywatel. Jeśli w Polsce dziś nie czyni tego wprost, choć w kwestii braku pomocy dla uchodźców jego głos jest wyraźny, to katolicy i inni chrześcijanie, idąc za własnym sumieniem, mogą i powinni wyrażać głos sprzeciwu. I to czynią. Będąca dzisiaj u władzy grupa polityczna stara się pokazać kościołowi, że tylko ona może dać gwarancje polityczne dla nauki kościoła. Nic bardziej niebezpiecznego dla Kościoła niż ulec pokusie, by dla realizowania misji religijnej popierać kogoś politycznie. Żadna partia i żadna władza mimo najszczerszych zapewnień nie realizują w pełni Ewangelii. Rozdział kościoła od państwa jest najlepszym rozwiązaniem (Dostatni, 2017, s. 13). Obecnie partia rządząca kontestuje kompromis w kwestii przyjętej Konstytucji z kwietnia 1997 roku, również dotyczącej relacji państwo - kościół ${ }^{5}$ jaki ukształtował się w latach 90. Obejmował on religię w szkołach, krzyż w Sejmie, konkordat, bardzo restrykcyjne prawo aborcyjne, hojne finansowanie Kościoła katolickiego przez państwo, „wartości chrześcijańskie” wpisane do kluczowych ustaw plus pomnik Jana Pawła II w każdej gminie. Ten kompromis był wtedy zrozumiały. W okresie niepewności transformacji Kościół katolicki pozostawał ważną instytucją źródłem stabilności i gwarantem poczucia bezpieczeństwa wielu obywateli. Lewica i liberałowie lat 90. czuli się albo wdzięczni za faktycznie chlubną działalność kościoła z lat 80., albo jako byli członkowie PZPR - mieli wobec kościoła poczucie winy. Dziś ten kompromis nie jest możliwy do utrzymania. Niszczy go z jednej

${ }_{5}$ Konstytucja Rzeczypospolitej Polskiej z dnia 2 kwietnia 1997 r., wyd. II, art. 25 pkt $1-5$, s. 7. 
strony PiS i sprzymierzona z nim część środowisk katolickich. Gotowe są używać instytucji państwa do tego, by narzucać obywatelom swoje poglądy, także tam, gdzie zdecydowanie rozmijają się one ze społecznymi nastrojami. Najbardziej wyraziście pokazały to „czarne marsze”, ale widać to także w stosunku rządzących do antykoncepcji czy w ich czysto ideologicznym sprzeciwie wobec finansowania in vitro. Dołączmy do tego intensyfikację państwowego kultu Jana Pawła II, dalsze zlewanie się kościelnej liturgii z rytuałem państwowym, a otrzymamy mieszankę, która może wywołać reakcję. Z tych powodów pokolenie dzisiejszych 20- i 30-latków na nowo otworzy debatę o państwie i kościele. Skupić się ona może na trzech głównych obszarach:

1. Na kwestiach bioetycznych. Głos związków wyznaniowych w tych sprawach powinien być ważną częścią debaty, nie może być jednak jak do tej pory w Polsce - decydujący.

2. Na kwestii finansowania kościoła przez państwo. Nie ma nic złego w tym, by organizacje religijne ubiegały się o państwowe pieniądze. Ale powinny to robić na takich samych zasadach jak organizacje świeckie.

3. Ostatnia kwestia to zakres nakładania się na siebie porządków kościelnego i państwowego. Czy prawo powinno szczególnie chronić „uczucia religijne”, skoro nie chroni w żaden specjalny sposób uczuć związanych z niereligijnymi światopoglądami? Zmiany relacji państwo-kościół wymagać będą współpracy części osób wierzących. Także one dostrzegają jednak, że obecny model politycznego katolicyzmu po polsku szkodzi samemu chrześcijaństwu. Im dalej PiS i związane z nim skrzydło Kościoła katolickiego przeciągać będą w najbliższych latach linę w swoją stronę, tym bardziej w przyszłości wahadło będzie musiało się wychylić w drugą. Już dziś warto pracować nad konkretnymi propozycjami odpowiadającymi na tę zmianę (Majmurek, 2017, s. 16).

Niepokój budzi przedziwny alians władzy publicznej z ONR-em. Wywodzenie wzorców patriotyzmu z tej tradycji nie ma nic wspólnego z budowaniem dobra wspólnego. W stosunkach państwa z kościołem kwestia przyznawania dotacji i inne kwestie finansowe powinny być rozstrzygane na zasadzie równego traktowania wszystkich podmiotów. Nie da się uczciwie kupić głosu poparcia za pieniądze. Kościół musi być bardzo uważny, nie może domagać się przywilejów. Niepokoi perspektywa, która już się rysuje, że konflikty społeczne będą rozwiązywane na ulicy lub też pojawi się wariant siłowy. Społeczeństwo jest dziś bardzo podzielone. 
Kościół musi jednoczyć, wzywać do pojednania i konsensusu. Także do przebaczenia. Taką rolę odgrywał w historii Polski, nie tylko najnowszej, i taką wielu myślących ludzi Kościoła chce odgrywać dalej. Ale może to czynić tylko wtedy, kiedy jasno i wyraźnie wskazuje się zagrożenia i wyraża swoje niepokoje (Dostatni, 2016, s. 33). W sobotę 7 stycznia 2017 roku na Jasną Górę przyjechało 2 tys. kibiców. Uroczystości celebrowali m.in. ks. Tadeusz Isakowicz-Zaleski i duszpasterz kibiców ks. Jarosław Wąsowicz. Ten ostatni mówił w kazaniu o niedawnym akcie intronizacji Jezusa - o trafności i potrzebie takich aktów publicznego wyznania wiary w Polsce świadczy według niego skala ataków na kościół, jakie przypuszczają wielbiciele Europy bez chrześcijańskich korzeni. „Widać, że szatan się piekli, jak zawsze, gdy dobro pokonuje zło" - mówił ks. Wąsowicz. Zapowiedział, że kibice podejmą nową inicjatywę: różaniec za Polskę i swoje środowisko. Ks. Wąsowicz nawiązywał do Narodowych Sił Zbrojnych. - My, podobnie jak żołnierze NSZ, nie chcemy Polski bez Boga i religii, chcemy chrześcijańskiej Europy, bo tylko odwołanie się do fundamentalnych wartości może pomóc jej dzisiaj obronić się przed unicestwieniem - z różańcami $\mathrm{w}$ ręku - mówił kibicowski duszpasterz. $\mathrm{Na}$ zdjęciach z pielgrzymki widać, jak m.in. ks. Isakowicz-Zaleski święci kibicowskie szaliki. Na niektórych z nich widać krzyż celtycki (symbol neofaszystowski, zakazany m.in. w Niemczech) oraz hasła: „Śmierć wrogom ojczyzny". Do pielgrzymki na blogu odniósł się jezuita o. Grzegorz Kramer: „W jednej z relacji fotograficznych zobaczyłem zdjęcie, które jest wymowne. Obok człowieka z napisem złorzeczącym wrogom (już nawet nie pytam, kogo dziś uważamy za wroga ojczyzny) stoją duszpasterze. Nie reagują. W mojej Ewangelii, w którą wierzę, przesłanie jest takie: Bóg posłał swojego Syna, aby ten dał życie za każdego człowieka, również za wrogów". 1 kwietnia 2017 roku ponownie na Jasną Górę zjechali narodowcy z całej Polski. Oprócz Młodzieży Wszechpolskiej, organizatora pielgrzymki, pojawili się też przedstawiciele ONR, Ruchu Narodowego, a także członkowie skrajnie prawicowego węgierskiego Jobbiku. Po mszy narodowcy przyjęli nowych członków do swoich organizacji. Po „Apelu jasnogórskim” przeszli z pochodniami z klasztoru pod pomnik Nieznanego Żołnierza. Skandowali: „Nie czerwona, nie laicka, tylko Polska katolicka”, „Nacjonaliści nadchodzą”, „Wielka Polska katolicka". Skomentował to wydarzenie ojciec Tomasz Dostatni, dominikanin, który stwierdził: „To była demonstracja, która niewiele ma wspólnego z pielgrzymkami na Jasną Górę. Nacjonalizm jest skrajnym wypaczeniem idei narodowej i nie powinien iść w parze z chrześcijań- 
stwem. Chyba że uczestnicy tego wydarzenia wysłuchaliby kazania, w którym byłaby mowa o tym, jak Kościół w swojej nauce społecznej rozumie zaangażowanie na rzecz drugiego człowieka. Albo czym dla katolika jest ojczyzna". Zwrócił również uwagę, że w sprawie nacjonalizmu Kościół w Polsce nie mówi jednym głosem. Są takie wypowiedzi jak ta prymasa Wojciecha Polaka, który mówi, że aprobata dla myślenia nacjonalistycznego jest niemalże heretycka. Warto też przypomnieć słowa abp. Stanisława Gądeckiego - że nacjonalizm jest przeciwieństwem patriotyzmu. Stwierdził, że osobiście zgadza się z prymasem i abp. Gądeckim. Nacjonalizm nie ma nic wspólnego z chrześcijaństwem. Zapytany o to czy Episkopat powinien zabrać głos w tej sprawie odpowiedział: „Bardzo bym się cieszył, gdyby tak się stało. Ale sprawa nie rozbija się tylko o to, czy biskupi coś poprą albo będą czemuś przeciwni. Przed kościołem wielkie duszpasterskie wyzwanie: co zrobić z młodzieżą, dla której spuścizna ONR i Młodzieży Wszechpolskiej jest jedynym wymiarem zaangażowania w społeczeństwo, w chrześcijaństwo, w Kościół" (Wilgocki, 2017, s. 4). 28 kwietnia 2017 roku biskupi polscy w dokumencie „Chrześcijański kształt patriotyzmu” podczas Konferencji Episkopatu Polskiego skrytykowali egoistyczny nacjonalizm. W rozmowie Michała Wilgockiego z ks. prof. dr. hab. Alfredem Wierzbickim ${ }^{6}$, który komentuje ten doniosły dokument. Dokument nie jest reakcją na konkretne wydarzenia, tylko ustosunkowaniem się do narastającego problemu. Mieliśmy ostatnio do czynienia z całą falą niepokojących zjawisk - najpierw niechęci do obcych, potem ataków agresji. W wielu miastach w Polsce obcokrajowcy byli bici. Do tego dochodzą manifestacje na stadionach czy budzące niepokój pielgrzymki ONR. Także wśród zjawisk pozytywnych, jak rekonstrukcje historyczne, biskupi zauważają niebezpieczeństwo banalizacji dramatycznej przeszłości. Jest i bieżący kontekst polityczny. Zupełnie niedawno padły zdania o Polakach lepszego i gorszego sortu. Biskupi nie odnoszą się do tej haniebnej segregacji wprost, ale piszą, że patriotyzm ulega upolitycznieniu. Wreszcie - biskupi mają świadomość, że z wielu ambon płynie głos narodowego szowinizmu. Dlatego ten tekst należy odebrać z wielką ulgą. Identyfikuje niebezpieczne zjawiska i pokazuje chrześcijańską wizję patriotyzmu. Na kolejne pytanie, co jeszcze mogą zrobić biskupi by powstrzymać falę nacjonalizmu i ksenofobi, ks. profesor odpowiada - Powinniśmy zrewidować programy katechetycz-

${ }^{6}$ Ks. prof. Wierzbicki jest kierownikiem Katedry Etyki Katolickiego Uniwersytetu Lubelskiego. 
ne pod kątem krzewienia wizji chrześcijańskiego patriotyzmu. Bardzo się ucieszyłem, że biskupi odwołują się w dokumencie do Jana Pawła II i jego wizji polskości jagiellońskiej. Można by uczyć o niej na katechezie. Patriotyzm Jana Pawła II był otwarty. On nie wahał się polskimi patriotami nazwać np. protestanckich biskupów. Chciałbym, żeby powstał list o naszym członkostwie i udziale Polski w Unii Europejskiej. Biskupi wiele miejsca poświęcili patriotyzmowi lokalnemu, a europejski pominęli. A on przecież też wpisuje się w tradycje polskości jagiellońskiej (Piwnicki, 2017, s. 146-164).

\subsection{Toksyczny patriotyzm}

Narodowcy i inni przedstawiciele narodowo-katolickiej prawicy, określający się mianem obozu patriotycznego, podkreślają przywiązanie do tradycyjnych polskich wartości zawartych w haśle: „Bóg, honor, ojczyzna"7. Hasło to otwiera pochody i manifestacje środowisk nacjonalistycznych, służąc, jako odium przeciwko lewakom, liberałom i kosmopolitom, czyli wszystkim, których uczestnicy tych zgromadzeń uważają za Polaków gorszego sortu. Hałaśliwie i skrajnie emocjonalnie demonstrowany patriotyzm ma dużą siłę przebicia. Wzniosłe cele i romantyczne uniesienia porywają sporą część młodzieży. Także w środowiskach niechętnych nacjonalistom często wyrażane jest przekonanie, że patriotyzm emocjonalny, oparty na mocno zakorzenionych kodach kulturowych, jest z natury rzeczy bardziej przekonujący i zrozumiały niż patriotyzm racjonalny, w którym interes narodowy pozbawiony jest romantycznej otoczki męstwa i poświęcenia. Pretensje do narodowo-katolickiej prawicy dotyczą więc nie formy demonstrowania patriotyzmu, ale jego zawłaszczania i pozbawiania innych prawa do uczuć patriotycznych, jeśli nie dość gorliwie oddają cześć symbolom narodowym i nie przeżywają euforycznie defilad wojskowych. Panuje również przekonanie, że hasła i symbole narodowe nie powinny być przedmiotem dyskusji, odnoszą się bowiem do wartości najwyższych, których nikt nie kwestionuje. Właśnie to przekonanie pozwala narodowym katolikom stroić się w szaty żarliwych patriotów, podczas gdy w istocie szkodzą interesom narodowym, zwłaszcza

7 Wprowadzonym na sztandary polskich jednostek wojskowych w roku 1943 po śmierci Władysława Sikorskiego. Do tego czasu na tych sztandarach widniał tylko napis „Honor i Ojczyzna”. Usiłuje się Polakom wpoić, że to co dzisiaj jest na sztandarach wojskowych ,było zawsze”. 
teraz, gdy to oni są u władzy. Cóż więc w istocie oznacza triada: Bóg, Honor, Ojczyzna i jak jest rozumiana przez większość prawicowych patriotów? We wszystkich wielkich religiach świata, a w chrześcijaństwie w szczególności, Bóg kojarzy się z dobrocią. Imperatyw czynienia dobra i miłości bliźniego jest podstawą etyki chrześcijańskiej. Wynika z tego postulat przyjaznego otwarcia na innych, gotowość śpieszenia im z pomocą, a w sytuacjach konfliktowych - uparte dążenie do porozumienia i wybaczanie win. Powołanie się na Boga nie jest ułatwieniem, ale przyjęciem trudnej, choć moralnie chwalebnej postawy. Polscy narodowcy nie mają zamiaru podporządkować się boskim nakazom, potrzebują Boga służącego ich celom. Przyczyną tej zuchwałej postawy jest mesjanistyczna egzaltacja, przekonanie, że Polska pod rządami prawicy broni wartości chrześcijańskich, zapomnianych i lekceważonych w zsekularyzowanej Europie $^{8}$. Robienie z Polski bastionu obrony wiary i tradycyjnych wartości nie zawiera żadnych bodźców prorozwojowych, oznacza natomiast erupcję bigoterii i ksenofobii. Otwiera to drogę do akceptacji poglądów skrajnych, do usprawiedliwiania przejawów gwałtu i przemocy, jako skutku ubocznego patriotycznego wzmożenia. Na rzecz tego wzmożenia usilnie pracują ideolodzy prawicy. Z obozu władzy nieustannie słychać ostrzeżenia przed związanym z uchodźcami zagrożeniem islamizacją kraju, wzrostem przestępczości, terroryzmem lub epidemiami. Celowo rozbudzany jest lęk przed cudzoziemcami, zwłaszcza Niemcami i Rosjanami, rzekomo zainteresowanymi pozbawieniem Polski suwerenności (słynna teza Kaczyńskiego o kondominium). Nie ustaje także krytyka środowisk lewicowych i liberalnych, które domagają się przyjęcia uchodźców i otwarcia obyczajowego na Zachód, co jest traktowane, jako zdrada narodowych ideałów. Prawicowi publicyści nie oszczędzają nawet papieża Franciszka, ich zdaniem zbyt tolerancyjnego i niedostrzegającego zagrożeń wskazywanych przez katolickich fundamentalistów. W języku narodowo-katolickiej prawicy słowo tolerancja ma znaczenie pejoratywne. Patrioci mają być ludźmi walki o słuszną sprawę, a nie tolerancyjnymi mięczakami. Wiara w Boga ma służyć mobilizowaniu prawdziwych Polaków do walki zarówno z obcymi, jak i z własnymi przeciwnikami (Sikorski, s. 30). Dla polskich nacjonalistów integracja z Unią Europejską to największe zło, jakie może się przydarzyć w naszym kraju.

${ }^{8}$ Europa jawi się dla narodowców miejscem pogańskiego zła, należy ją repoganizować. Kultura europejska jest często określana jako kultura śmierci. Permisywizm europejski jest dla tego środowiska nie do zaakceptowania. 


\subsection{Nienawiść w Polsce. Anomia}

Po śmierci prof. Barbary Skargi w „Gazecie Wyborczej” ukazał się jej tekst pt. Przeciw nienawiści $i^{9}$. Był przestrogą przed nadchodzącą erą. Przestrogą, której nikt nie posłuchał. Ktoś kiedyś powiedział, że my, Polacy, lubimy sielanki. Tak może było, tak nie jest. Okazuje się, że nie jesteśmy narodem łagodnym, że potrafimy szczerzyć kły, warcząc nie na obcych, lecz na siebie nawzajem. Coraz szerzej wzbiera piana nienawiści, niszcząc nasze życie społeczne. Może, więc warto przywołać przesłanie autorki o nienawiści, o tym uczuciu, które nie liczy się z nikim i niczym. Może warto uprzytomnić sobie, czym ono jest i jakie powoduje spustoszenia?

To uczucie, które nie umie patrzeć na świat inaczej niż z perspektywy negacji. Nawet w tym, co innym wydaje się cenne, ważne, dostrzega wyłącznie podstępne działanie, upadek, oszustwo, bo takim jest dla niego naturalny stan ludzkiej kondycji. Nienawiść nie zmierza do ulepszenia, przeciwnie, zastana sytuacja jej odpowiada, z satysfakcją stwierdza każdy błąd potwierdzający słuszność jej nastawienia, każde nieudane przedsięwzięcie. Przede wszystkim zaś tym nastawieniem chce zatruć wszystkich dookoła, zaczyna się sączyć, aż ogarnia społeczność. Nienawiść bez podstaw, bez wyjaśnienia dlaczego, nienawiść szukająca przedmiotu, by się na nim skupić, by ten przedmiot zniszczyć, choć najczęściej ten przedmiot na jej ataki nie zasługuje. Rodząca się nienawiść jeszcze nie wie, w jaką stronę się zwróci. Nie orientuje się według takich czy innych racji. Dlatego często uderza na ślepo, czasem w kogoś słabego, niezdolnego do obrony, czasem przeciwnie, w tych, co są lepsi, czasem z jakichś ukrytych pobudek, u nas najczęściej politycznych, obiera sobie ofiarę. „U człowieka powodującego się resentymentem - pisał Max Scheler - zazdrość, zawiść, złośliwość, utajona żądza zemsty osadzają się na dnie duszy oderwane od określonych przedmiotów" ${ }^{10}$. Co więcej, stają się trwałymi nastawieniami, niemal chorobliwą obsesją. Ksiądz Tischner zaś dodawał: posiadając przerażającą łatwość wynajdywania pretekstów, nienawistnicy „rozkoszują się już samym podejrzeniem, gmeraniem w złościach i krzywdach pozornych, szperają we wnętrznościach swej przeszłości i teraźniejszości, poszukując ciemnych, zagadkowych historii, które po-

9 „Gazeta Wyborcza” z dn. 19-20 marca 2005.

${ }^{10}$ Max Scheler (1874-1928), filozof niemiecki. Dorobek jego obejmuje publikacje z zakresu etyki, życia emocjonalnego, teorii poznania, filozofii religii, filozofii społecznej, antropologii i socjologii. 
zwalają im odpływać w dręczące domysły i upajać się trucizną własnej złośliwości, rozdzierają najstarsze rany, rozkrwawiają od dawna zagojone blizny, czynią złoczyńców z przyjaciela, żony, dziecka i z wszystkiego, co dla nich najbliższe". Czytając te słowa, odnosi się wrażenie, że ks. prof. przewidział listę Wildsteina, jej smutne konsekwencje, a zapewne także postępowanie niektórych naszych polityków. Czy nienawiść rodzi się z krzywdy? Bywa tak, że człowiek, który doznał niesprawiedliwości, przemocy, jakiegoś zła, którego nie jest w stanie przezwyciężyć, zaczyna nienawidzić. Tę gwałtowną reakcję można zrozumieć, trudniej ją usprawiedliwić. Ilu ludzi cierpiało podczas wojny, a jednak potrafili przezwyciężyć żal, wybaczyć. Nie w każdym skrzywdzonym człowieku rodzi się mściwość. Zemsta nic nie daje, prócz chwilowej złudnej satysfakcji, jest bowiem odpowiedzią niesprawiedliwości na niesprawiedliwość, zła na zło. Ten więc, kto ma poczucie swego Ja, kto nie chce się zniżać do tych, którzy zło czynią, nawet gdy dotknęło go straszne nieszczęście, potrafi je zapomnieć, oddając sąd nad nim w ręce prawa. Krzywda jest raczej pretekstem dla tkwiącej w człowieku złości. Przyczyny tej złości trzeba szukać gdzie indziej, gdzie? To prawda, że sprzyjają jej społeczne sytuacje. Tam, gdzie kultywuje się równość, a jednocześnie panuje ogromne zróżnicowanie pod względem faktycznej władzy i faktycznego posiadania, wzmaga się ładunek resentymentu. Tam się znajdą zręczni demagodzy, którzy go wykorzystają do własnych, zazwyczaj niskich celów. Łatwo dziś możemy to obserwować wokół. A przecież są także inni, którzy się resentymentom nie poddają mimo wszelkich sprzyjających faktów. Noszą zatem jakiś mocny pancerz, który chroni nawet przed naturalnym wybuchem złości. Czym jest ten pancerz? Zapewne odpornością moralną, a także poczuciem własnej godności. Kto jest podatny na nienawiść, w kim to zło znajduje dla siebie odpowiedni grunt? Na pozór każdy może ulec nienawiści. Tak jednak nie jest. Jak uczy obserwacja otaczających nas faktów, poddają się jej najczęściej ci, którzy mają rozchwianą tożsamość, którym trudno jest zbudować własną osobowość, ludzie w gruncie rzeczy słabi, jakby pozbawieni mocy bycia sobą, a zatem ulegający wpływom, tym lub innym nastrojom społecznym, na pół świadomi swego bra$\mathrm{ku}$, jednocześnie drażliwi ambicjonerzy reagujący na byle drobiazg odruchem sprzeciwu, niechęcią do otaczającego świata. W takich ludziach rośnie napięcie między pragnieniem bycia kimś i świadomością własnej małości, rodzi się też chęć zaznaczenia swej obecności. A od tego już tylko mały krok do tego, by zaczęła pożerać nas zawiść, ona najczęściej jest u źródła. Wówczas jakiś fakt, nawet drobny, rodzi chęć odwetu. A odwet 
nie przebiera w środkach, każdy wówczas jest dobry, każde nieuzasadnione oszczerstwo, każde posunięcie, choćby przeczyło podstawowym wartościom moralnym, a nawet prawu. Gdy nienawiść zżera jednostkę, jest to sprawa jej sumienia. Nędzne to, ale nie wychodzimy tu poza sferę etyki. Lecz jad się sączy i zaraża otoczenie. Wówczas nic już nie może powstrzymać fali nienawiści, mały pretekst i rozlewa się szeroko. Skutki są zawsze fatalne. Na nienawiści nigdy niczego nie zbudowano. Ona chce tylko rozliczyć, zniszczyć, poniżyć zwłaszcza tych, w których dostrzega głównych nieprzyjaciół. Wroga zawsze można znaleźć, a tłum pobudzić jest łatwo. W rezultacie nienawiść jak błoto, maź potrafi pokryć wszelkie społeczne działanie, lepka i niszcząca - gotowa zrujnować nawet to, co najlepsze. Niestety. Możemy się o tym przekonać, bo znów dziś pokazuje swą twarz. I nikt na jej działania nie reaguje, nikt nie potępia, przeciwnie, są tacy, którzy mają wciąż na ustach moralną rewolucję, a poddają się jej z ochotą, jakby tęsknili za szubienicami (Iwanowa, 2019). Może, więc pora powiedzieć „dosyć”? Może przyszedł czas na protest ludzi uczciwych, tych wszystkich, których, gdy patrzą na te pełne nienawiści działania, ogarnia przerażenie? Dlaczego pozwalamy na podobne praktyki, dlaczego pozwalamy niszczyć społeczną tkankę? (Skarga, 2009).

\subsection{Spór kulturowy o integrację z Unią Europejską w Polsce. Dystopia}

W październiku 2018 roku ukazał się w „Newsweeku” wywiad z Jacquesem Rupnikiem ${ }^{11}$ pod tytułem Coraz mniej Unii. W swojej enuncjacji Rupnik m.in. mówił: Podobnie jak w 1989 roku Europa Środkowa powracała na scenę, ale tym razem już nie jako źródło wiary w demokrację, lecz jako powód do zmartwienia i zwątpienia. Podział na Zachód i Wschód, który został niemal zapomniany, znowu stał się aktualny. Przyczyną tego jest regres demokracji i tożsamościowo-nacjonalistyczna gorączka wywołana kryzysem uchodźczym. To, co wydarzyło się w ciągu ostatniego ćwierć wieku w Europie Środkowo-Wschodniej, nie ma precedensu. Jeszcze nigdy w historii nie odnotowano takiego tempa konwergencji gospodarczej i społecznej. Nieważne, jaki wskaźnik ekonomiczny czy społeczny weźmiemy pod uwagę - czy będą to zarobki, długość życia, czy styl życia lub konsumpcja - widać niewiarygodne wręcz zbliże-

11 J. Rupnik (ur. 1950) był doradcą prezydenta Czech Vaclava Havla. Jest jednym z najważniejszych francuskich znawców Europy Środkowej, autorytetem i współautorem wielu książek o tematyce politologicznej. 
nie się Europy Środkowej do Zachodu. Niestety, dawne podziały powróciły z ogromną siłą. I to w momencie, którego nikt się nie spodziewał. 30 lat temu Rupnik napisał książkę o Europie Środkowej zatytułowaną Inna Europa. Wtedy chodziło o kwestie ekonomiczne i polityczne. Dziś Europa Środkowa znowu jest inna. Tylko, że jest inna inaczej. Tym razem chodzi o różnice kulturowe, o stosunek do uchodźców. W 1989 roku Polska i Węgry chciały naśladować Zachód. Teraz Kaczyński i Orban Zachodem straszą. Mówią, że nie do takiej Europy chcieli przynależeć (Piwnicki, 2017). Przed laty dysydenci, Adam Michnik i Vaclav Havel, spotykali się na granicy czesko-polskiej, żeby omówić strategię działania opozycji. W roku 2016 Kaczyński i Orban spotkali się w Krynicy, żeby zaproponować kulturalną kontrrewolucję wymierzoną w Zachód. Zachód jest przez nich opisywany, jako społeczeństwo permisywne, dekadenckie, skazane na klęskę - Węgry i Polska mają być dlań alternatywą. Orban niedawno mówił, że chce być liderem ,prawdziwej” Europy - konserwatywnej i chrześcijańskiej. Podkreślał, że Węgry znajdują się w awangardzie. Stwierdził m.in.: „Najpierw byłem ja, a potem brexit, Trump, a teraz Salvini. I kto tu ma rację?" - tak można sparafrazować jego stosunek do Unii w Polsce. Unia była dla naszego kraju marzeniem o demokracji, dobrobycie i bezpieczeństwie narodowym. Niewielu Polakom przyszłoby pomyśleć, że przejdziemy i to po kilkunastu latach od utopii (szczęśliwości) do dystopii (gdzie panuje zło). Aktualnie dwie trzecie Polaków postrzega imigrację w negatywnym świetle, ale w Czechach czy na Słowacji jest jeszcze gorzej, bo ten odsetek wynosi 90 proc. społeczeństwa. Jest całkiem prawdopodobne, że jeśli Zachód będzie nadal postrzegany jako rzecznik otwartych granic i multikulturalizmu, to Europa Środkowa będzie się od Zachodu coraz bardziej oddalać. I w rezultacie wybierze „społeczeństwo zamknięte”, dokładnie odwrotnie niż w 1989 roku, kiedy wybrała społeczeństwo otwarte. Ale istnieje też gorsza możliwość, nacjonalpopulizm, który nie jest przecież wynalazkiem Europy Środkowej (Wojciechowski, 1998). Podobne tendencje istniały od dawna na Zachodzie. Tyle tylko, że tam partie populistyczne nie sprawowały władzy. Ale teraz to się zmieniło. Populiści współrządzą w Austrii, sprawują władzę we Włoszech. Populizm nie jest już tylko fenomenem wschodnich rubieży Unii, jest również fenomenem środkowego zachodu Europy. Chodzi o kraje bogate, korzystające z globalizacji, które nie chcą się dzielić bogactwem z innymi - choćby z biedniejszymi regionami. To jest swego rodzaju fiskalna rewolta. Populizm zachodni ma wiele cech wspólnych z populizmem środkowoeuropejskim - odrzucenie liberalizmu kulturo- 
wego i niechęć do imigracji. Najważniejsze pytanie brzmi: w którym kierunku będzie zmierzać Europa? Czy Europa Środkowa wybierze zakotwiczenie na Zachodzie? Czy raczej jej wolta stanowi zapowiedź rozpadu całej Unii? Uważa się, że Europa jest na rozdrożu. Populiści odnoszą triumfy, reżimy autorytarne są coraz bardziej w modzie. Wszystko, co uważaliśmy za oczywiste, przestało być oczywiste - tak jak projekt europejski. Do niedawna Unia działała z automatu, ale to się skończyło. Są dwie możliwości: albo wybierze wspólną przyszłość, albo nastąpi demontaż Unii Europejskiej. Nie chodzi o to, że Unia Europejska rozpadnie się z dnia na dzień, bo takie rzeczy się nie zdarzają. Po prostu będzie się stopniowa rozpuszczać. Przyszłość będziemy musieli wybrać wspólnie - Zachód i Europa Środkowa. Problem polega na tym, że niestety nie łączy nas coś, co można nazwać wspólnym europejskim marzeniem. Zwykło się mówić, że dziś mamy do wyboru Europę Orbana lub Europę Macrona $^{12}$. Ale to nie oddaje istoty problemu. Różne narody miały zawsze różne europejskie marzenia (Rupnik, 2018). Porównując twarde dane o Unii - ofertę gospodarczą, skalę pieniędzy - trudno uwierzyć, że europejska opowieść zawiodła. Stało się tak, bo w Polsce nigdy nie zdecydowano się na wyciągnięcie konsekwencji z podstawowej, fundamentalnej dla powojennego Zachodu doktryny praw człowieka. Idealizując Unię, przez dekadę tłumaczono to sobie niedostatkami polskiej polityki. Sprzyjało temu samooszukiwaniu się, że w Unii Polska jest tak naprawdę krótko. Rok rządziło schyłkowe SLD, więc prawa człowieka mogły poczekać. Potem przez dwa lata rządziło PiS, w którego czasach problemem była pierwsza fala populizmu pod postacią Samoobrony i Ligi Polskich Rodzin. Uznano ten czas za „odbicie wahadła” po kosztownym wejściu do Europy, prawa człowieka znów musiały zaczekać. Osiem lat rządów Platformy Obywatelskiej miało być czasem, gdy Polska rzeczywiście przyjmie europejskie standardy cywilizacyjne. Tak się nie stało, ale znów wytłumaczyliśmy to sobie właściwościami tutejszej władzy. Europeizacja za czasów PO-PSL znalazła wyraz tylko w projektach infrastrukturalnych - mówiliśmy sobie - bo autostrady, drogi ekspresowe i linie tramwajowe nie wchodzą w konflikt z kościelnym konserwatyzmem oraz

12 Marcon w liście do Europejczyków wzywał by nie oddawać pola populistom. Postulował stworzenie: europejskiej straży granicznej, polityki azylowej i europejskiego sojuszu wojskowego. Domagał się odgórnego ustalenia płacy minimalnej i skoordynowanej walki ze skutkami zmian klimatycznych. Postulował, by unijna agencja chroniła państwa członkowskie przed dezorientacją i ingerencją innych państw w wybory. 
neoliberalną doktryną, wedle której państwo ma nie mieszać się do gospodarki, która w dobie globalizacji traktuję słabszych coraz brutalniej. Prawa człowieka znów musiały czekać na lepsze czasy (Krasowski, 2016 s. 183-223). Historia ruszyła błyskawicznie w 2014 roku. Załamanie w stosunkach z Rosją, kryzys uchodźczy, gwałtowna eskalacja wojny w Syrii i zapaść polityczna w Stanach Zjednoczonych spowodowały, że Unia jest zdana sama na siebie. Wydarzenia na Węgrzech pozwoliły to podejrzewać - ale tak naprawdę dopiero dojście PiS do władzy i praktyka jej sprawowania pokazały, że Unia jest organizacją o słusznych poglądach, szlachetnych celach, ale pozbawioną prawdziwej mocy oddziaływania cywilizacyjnego. Jak słabą i powolną, pokazały spory PiS z Komisją Europejską o przestrzeganie praworządności oraz wycinkę Puszczy Białowieskiej. Ani jednego, ani drugiego Wspólnota nie była w stanie powstrzymać, zanim zło zostało wyrządzone. Powstrzymanie zamachu na Puszczę - ostatni taki las w Europie - zajęło instytucjom unijnym dwa lata. Wycinki zaczęły się w 2016 r., a wyrok Trybunału Sprawiedliwości UE zapadł w 2018 roku. Z konstytucją jest jeszcze gorzej. PiS zdeptał ją po raz pierwszy już chwilę po wyborczym zwycięstwie, w 2015 roku, gdy zarządzany przez Jarosława Kaczyńskiego Sejm bez żadnej podstawy prawnej uchwalił unieważnienie wyboru sędziów Trybunału przez posłów poprzedniej kadencji (Skarżyński, 2018). W sierpniu 2018 roku Tomasz Targański z „Polityki” przeprowadził wywiad z amerykańskim historykiem prof. Timothym Synderem ${ }^{13}$ o groźbie tyranii, oszustwach Donalda Trumpa i o tym, dlaczego Polska nie przetrwa bez Europy, który m.in. stwierdził, jako konserwatysta zawsze obawiał się szybkich, radykalnych zmian w sprawach zasadniczych dla funkcjonowania państwa. Skojarzenia były w tym wypadku jednoznacznie złe powinny budzić podejrzenia każdego rozsądnie myślącego obywatela. Negatywne konsekwencje mogą mieć dwojaki charakter i dadzą o sobie znać z pewnym opóźnieniem. Największym zagrożeniem wewnętrznym jest oligarchizacja Polski. Brak praworządności przede wszystkim uderzy bowiem

13 Timothy Synder (ur. 1969 r.), amerykański historyk, badacz nacjonalizmu i dziejów Europy Środkowo-Wschodniej, profesor uniwersytetu w Yale. W Polsce wymieniany obok Normana Davisa jako jeden z nielicznych zagranicznych znawców dziejów naszego kraju. Autor książki o ludobójstwie w Europie Środkowo-Wschodniej w latach 1933-1945 (Skradzione Ziemie Europa między Hitlerem i Stalinem, 2015) oraz słynnego już eseju $O$ tyranii. W 2014 roku odznaczony przez prezydenta Bronisława Komorowskiego Krzyżem Oficerskim Orderu Zasługi RP za pracę naukowo-badawczą i popularyzowanie wiedzy o historii Polski. 
w zwykłych obywateli oraz małych przedsiębiorców. Wielkie koncerny wiedzą przecież, jak radzić sobie w warunkach osłabienia rządów prawa. Mają pieniądze i dostęp do osób, które podejmują decyzje. Polskiemu rządowi może się wydawać, że jest bardzo sprytny: zmian w sądownictwie chciał dokonać latem, gdy urzędnicy z Brukseli byli na wakacjach. Ale cyniczne założenie, że Unia Europejska jest grą, gdzie wszyscy chcą przechytrzyć siebie nawzajem, to błąd. Każdy kraj członkowski wzmacnia Europę i coś jej daje. Chodzi o to, by Polska również coś Europie dała. Budowanie taktycznego sojuszu z Węgrami, opartego na autorytarnym charakterze obu rządów, jest krótkowzroczne. Ma on sens tylko w wypadku, jeśli chcemy w Europie kogoś ograć. Unia polega jednak na tym, by w atmosferze zaufania budować największą gospodarkę świata. W dłuższym okresie Unia zacznie planować swoją przyszłość bez wschodnich partnerów, ponieważ dwa autorytarne rządy, które dezorganizują wspólnotę od środka, to już za dużo. Skutki mogą być bardzo bolesne - nawet bez sankcji. Aktualnie akcje Polski w Brukseli stoją dość nisko. Jeśli Francja i Niemcy proponują zacieśnić integrację, to w tej sytuacji pominięcie Polski przyjęte zostanie ze zrozumieniem, a nawet ulgą. Realizacji tego scenariusza należy się obawiać. Polacy powinni wiedzieć, że Polska nie może istnieć bez Europy. Wielka Brytania poradzi sobie bez Europy, ale ze względu na swoje szczególne położenie i potencjał gospodarczy. Polska, aby zachować suwerenność, musi być częścią jakiegoś międzynarodowego układu. Unia Europejska nie jest idealna, ale tworzy warunki, w których państwowość jest możliwa. Nie można wyobrazić sobie suwerennej Polski bez Europy. Stosunek Polski do Europy jest dziwnie nieokreślony. Unia Europejska nie jest tworem imperialnym, jej celem nie jest narzucanie Polsce czegokolwiek ani likwidacja jej kultury. Unia to związek państw, a przede wszystkim sposób na dalsze istnienie europejskich narodów, które w ciągu poprzednich stuleci cały czas ze sobą walczyły. Jeśli spojrzymy na dzieje kontynentu, przekonamy się, że państwa w Europie zwykle funkcjonowały bądź w ramach unii (albo federacji), bądź w ramach jakiegoś imperium. Dziś jedną z tych rzeczywistości reprezentuje Unia Europejska, drugą zaś Rosja. Trzeciej drogi nie ma. Oddalając się od jednej, przybliżamy się do drugiej (Synder, 2018). Warto przywołać kolejny wywiad dotyczący kondycji Polski i Europy, który Jarosław Kurski i Bartosz Wieliński przeprowadzili z Fransem Timmermansem ${ }^{14}$ pod koniec 2018 roku. Polityk

14 Frans Timmermans - ur. w 1961 r., pierwszy wiceprzewodniczący Komisji Europejskiej, polityk holenderskiej Partii Pracy, lider Europejskich Socjalistów w przyszłorocznych wyborach do europarlamentu, katolik, ojciec czworga dzieci. Politycy 
holenderski mówił wiele o Polsce i jego stosunku do Polaków. Przywołał fakty z historii II wojny światowej, mówił o tym, że Polacy Holendrów wyzwolili w 1944 roku spod okupacji hitlerowskiej, a Brytyjczycy potraktowali ich skandalicznie. Obwiniali ich o niepowodzenie operacji desantowej „Market Garden” [próba opanowania mostów na Renie we wrześniu 1944 roku]. Mówiąc o roli Polaków w wyzwoleniu Holandii uważa, że spłaca ten dług, jako holenderski patriota. Jest z pokolenia, które w mniejszym lub większym stopniu dorastało w cieniu wojny. Uważa, że młodzi ludzie nie zdają sobie sprawy, czym była wojna i że pokój jest wielką wartością. Podkreśla, że z podręcznika do historii trudniej czerpać naukę niż z przeżyć własnego pokolenia. Dlatego to wielkim obywatelskim obowiązkiem jest przypominanie, do czego Europejczycy byli zdolni, jak nisko potrafili upaść. I dlaczego zawsze trzeba rozróżniać nacjonalizm od patriotyzmu. Dziś w Polsce te pojęcia się łączy. Rząd rozwija mit ciemiężonej przez wieki nieskazitelnej ofiary i przestrzega, że nasza suwerenność znowu jest zagrożona - tym razem przez Europę. W 2018 roku, gdy podczas debaty ówczesna premier Polski Beata Szydło wiele mówiła o suwerenności narodowej, Frans Timmermans odpowiedział jej, że po raz pierwszy od wieków Polska ma pełną kontrolę nad granicami. Wcześniej, jeśli w potęgę rosły Niemcy, granice Polski przesuwały się o kilkaset kilometrów na wschód. Jeśli w siłę rosła Rosja, granice przesuwała o kilkaset kilometrów na zachód. Gdy silni byli obaj sąsiedzi, Polska znikała z mapy. Obecnie nikt nie śmie ruszyć polskich granic. Polska nie zawdzięcza tego nacjonalizmowi, tylko międzynarodowej współpracy z NATO i Unią Europejską. Stwierdził, że stawianie wyłącznie na narodową suwerenność nie ma sensu. Polska sama nie będzie w stanie uporać się z presją Rosji. Przypomniał jak 20 lat temu toczył spory z liberałem Fritsem Bolkesteinem, który uważał, że nie wolno rozszerzać NATO, bo to poróżni Zachód z Rosją. Nie chciał też rozszerzania Unii. Pomyślmy, jak dziś wyglądałaby Europa, gdyby adwersarz Timmermansa i myślący jemu podobnie postawili na swoim. Polska byłaby w takiej samej sytuacji jak Ukraina (Timmermans, 2018). Inny amerykański polityk prof. George Friedman ${ }^{15}$ od lat zapowiadał, że Polska będzie regionalnym mocarstwem i stanie na czele Międzymorza, koalicji

PiS go nie znoszą. Dostał order od Bronisława Komorowskiego - Krzyż Wielki Orderu Zasługi RP. A Krzyż Oficerski od Lecha Kaczyńskiego.

15 George Friedman - ur. w 1949 r., amerykański politolog, doradzał wielu generałom armii USA. W 1996 r. założył Stratfor - think tank zajmujący się geopolityką, który jest także prywatną agencją wywiadu. 
państw Europy Środkowo-Wschodniej od Bałtyku po Morze Czarne. Rosja jego zdaniem to kolos na glinianych nogach, a Niemcy słabną, bo za bardzo polegają na eksporcie. Polska ma przestać się uważać za ubogiego krewnego i prowadzić politykę zgodną ze swoim potencjałem. Profesor, mówił Polakom, że Polska jest regionalną potęgą. Powinna ustanowić własną agendę i mówić „nie” innym państwom. Dodał stwierdzenie, że Unia Polaków upomina, wy nic sobie z tego nie robicie. Waszym celem jest zachowanie suwerenności i niedopuszczenie do sytuacji, aby UE mogła wam coś narzucać. Polski rząd pokazuje słabość UE, ignorując oświadczenia Timmermansa. Polityka zagraniczna obecnego rządu jest skuteczna w ignorowaniu zaleceń UE, ale dużo mniej w pozyskiwaniu partnerów i wygrywaniu czegoś dla siebie, jak w przypadku wyboru Donalda Tuska na szefa Rady Europejskiej: 1 do 27. Georg Fridman konkludując stwierdził, że nie wie, czym ma być europejski projekt. Uważa, że oparty jest na bardzo prostych założeniach, nie chcemy więcej wojny, a żeby osiągnąć ten cel, zapewnimy Europie dostatek. Stwierdził również, że nie ma jednego doświadczenia europejskiego: greckie jest inne niż polskie, a polskie różne od niemieckiego. Nie stworzono europejskiej tożsamości. UE jest tworem traktatowym, nie krajem, nie wzbudza u swoich obywateli lojalności, i nic dziwnego, że kiedy główny cel Unii okazał się nieosiągalny, zaczęła się sypać. Brytyjczycy wychodzą, Polacy Brukselę ignorują. Nie ma jak utrzymać jedności i patriotyzmu, kiedy nie istnieje kraj, który można by kochać. Problemem Unii nie jest brak wojny domowej, ale brak chętnych do umierania za Europę podsumował sarkastycznie (Friedman, 2017). Część rządzących w Polsce, popiera jego stanowisko. Beata Szydło wykorzystała atmosferę po zamachu terrorystycznym w Manchesterze, aby zaatakować „poprawność polityczną” zachodniej Europy, mówiąc w Sejmie m.in.: „Nie będziemy uczestniczyć w szaleństwie brukselskich elit. Nie damy się zaszantażować i nie ulegniemy poprawności politycznej! [...] Dokąd zmierzasz, Europo? Powstań z kolan i obudź się z letargu, bo w przeciwnym razie codziennie będziesz opłakiwała swoje dzieci!”. Analizując sytuację w Polsce od kilku lat, zauważyć można hermetyzację naszego kraju wobec świata zewnętrznego. Elity rządzące ,żywią” społeczeństwo lękiem, wrogością, a nawet wojną. Jest to charakterystyczne dla stanu dystopii, tj. miejsca, gdzie rzeczy mają się źle. Pocieszeniem w tej kwestii może być fakt, że 84 proc. obywateli Polski jest przeciwnych polexitowi. Nawet wśród wyborców PiS aż 76 proc. to przeciwnicy opuszczenia UE. To jedyny powód, dla którego antyeuropejski PiS udaje dziś partię proeuropejską (Beniuszys, 2019). 


\subsection{Unia Europejska o niepraworządności}

Postrzeganie praworządności nie jest nową polityczną fanaberią UE. Jest częścią składową procesu integracji, która w rozszerzającej się i zmieniającej UE ulega stałej metamorfozie. Od początku integracji była oczywista. Aktualnie za sprawą powiększenia grona państw członkowskich oraz skonsolidowania procesu integracji. Jej jednoznaczna artykulacja staje się konieczna w gronie dużej rodziny państw europejskich uznających te same uniwersalne wartości, mimo tego, że mają odmienne kultury polityczne. Również na poziomie unijnym przewidywalność i jednoznaczność prawa, jego niedyskryminacyjne stosowanie oraz jednoznaczne wytyczanie unijnych instytucji i państw członkowskich stanowią następnie niezbędne kroki do zintensyfikowania procesu integracji. Co jest niezbędne w coraz bardziej zglobalizowanym świecie (Domaradzki, 2018, s. 81). Akcesja nowych państw warunkowana była (i jest) osiągnięciem ,„przez państwo kandydujące stabilności w dziedzinie instytucji gwarantujących demokrację, praworządność, respektowanie praw człowieka oraz poszanowanie i ochronę mniejszości" (tzw. pierwsze kryterium, określone w Deklaracji kopenhaskiej z czerwca 1993 r.), a postępy w tej dziedzinie są ściśle monitorowane w toku negocjacji akcesyjnych. Niekwestionowane do tej pory kierunkowe założenie wyrażało się więc w tym, że wszystkie państwa członkowskie są państwami demokratycznymi, natomiast te $\mathrm{z}$ nich, które dopiero budują ustrój demokratyczny (państwa przystępujące), przyjmują bez zastrzeżeń taki rozwój ustrojowy. Obecnie mamy do czynienia z państwami członkowskimi, które nie tylko budują autorytaryzm „u siebie”, przy wykorzystaniu demokratycznych środków objęcia władzy, lecz zapowiadają również „,budowę nowej Unii” od środka (na przykład w kontekście zbliżających się wyborów do Parlamentu Europejskiego). Populizm, ksenofobia i nacjonalizm są przeciwieństwem procesów integracji. Państwa nacjonalistyczne nie są w stanie zbudować żadnej wspólnej platformy współdziałania, z wyjątkiem sojuszy ad hoc, kończących się wcześniej czy później katastrofą. Czy Unia Europejska jest wobec takich zagrożeń bezbronna? Powszechna jest opinia, że w obliczu ubezwłasnowolnienia krajowych środków ochrony praworządności zawodzą również mechanizmy unijne, a Unia jest bezsilna wobec niepraworządnego państwa członkowskiego. Oczywiście, należy brać pod uwagę, że Unia Europejska nie jest w stanie decydować o ustroju państwa członkowskiego, mogą to zrobić jedynie wyborcy. Należy również brać pod uwagę specyfikę unijnych postępowań, które nie są na- 
stawione na „karanie” państw członkowskich, lecz na doprowadzenie do tego, aby prawo UE było przestrzegane, tj. aby państwo spełniało unijny standard. Stąd na przykład krytyka procedury art. 7 TUE, uruchomionej wobec Polski i Węgier, mija się z celem tej procedury, który nakierowany jest na konsekwentne oddziaływanie na państwo członkowskie, aby skłonić je do przywrócenia praworządności. Po kilku latach ,politycznego dialogu" Unia Europejska wyciągnęła jednak wnioski. Zwłaszcza wzięto pod uwagę, że niepraworządność może przybrać charakter trwały i nieodwracalny. Z jednej, więc strony skonsolidowano postępowania traktatowe. Zostało to umożliwione przez działalność orzeczniczą Trybunału Sprawiedliwości, który potwierdził w dwóch wyrokach z 2018 r., że sprawa praworządności w państwie członkowskim (zwłaszcza niezależności sądu i niezawisłości sędziego) jest objęta prawem UE, a więc może być badana w toku unijnych procedur. Otworzyło to drogę dla Komisji Europejskiej do występowania do Trybunału Sprawiedliwości ze skargami wobec państw niepraworządnych, a co ważniejsze, stworzyło nowe możliwości dla sądów krajowych do kierowania do Trybunału pytań prejudycjalnych dotyczących tej dziedziny. Nie przypadkowo, więc przedstawiciele reżimów niepraworządnych wyjątkowo wrogo odnoszą się tak do pytań prejudycjalnych, jak i do samego unijnego Trybunału. Z drugiej strony, Unia zaczęła paralelnie budować „system ochronny” wobec niepraworządnych państw członkowskich, nakierowany na ochronę interesów Unii i jej pozostałych państw członkowskich. System ten daje się już obecnie zdefiniować. Ma on również charakter elastyczny, uwzględniający, że niepraworządność w państwie członkowskim może mieć charakter przejściowy. Musi zarazem przewidywać radykalne działania (łącznie z wyrzuceniem z Unii) państwa członkowskiego, które przekształciłoby się w państwo autorytarne (Barcz, 2019, s. 22-23). 16 stycznia 2020 r. krytyczną rezolucję o praworządności w Polsce i na Węgrzech przyjął Parlament Europejski. Wzywa ona Radę UE oraz Komisję Europejską do zdecydowanych działań w ramach art. 7 oraz z pomocą Trybunału Sprawiedliwości w Luksemburgu. Komisja zdecydowała w ostatni wtorek, że zwróci się do TSUE o doraźne zamrożenie działania Izby Dyscyplinarnej SN do czasu pełnego wyroku TSUE. To wniosek w ramach skargi na Polskę w sprawie już obowiązującego systemu dyscyplinarnego dla sędziów, ale zawieszenie działania Izby Dyscyplinarnej przy okazji mogłoby też sparaliżować ewentualne nowe przepisy dyscyplinarne dla sędziów, których projekt oceniła właśnie Komisja Wenecka. Za uchwałą, która podsumowała środową debatę europejską o Polsce i Węgrzech, 
zagłosowało 446 europosłów. 178 było przeciw, a 41 wstrzymało się od głosu. Ponadto przeszła też poprawka (448 za, 182 przeciw) przypominająca, że europarlament popiera wprowadzenie zasady ,pieniądze za praworządność" w nowym budżecie UE po $2020 \mathrm{r} .{ }^{16}$ Pozostaje jeszcze otwarte, miejmy nadzieję retoryczne, pytanie - co stanie się, jeśli niepraworządność w państwie członkowskim nabierze trwałego charakteru i przekroczona zostanie cienka linia, za którą zaczynać się będą rządy autorytarne. Nie bez racji coraz częściej mówi się w kręgach ekspertów o „ukrytej”, czy „pełzającej” strategii exitu. Realny byłby wówczas raczej nie exit (wystąpienie), a inny scenariusz. Procedura wystąpienia z Unii (art. 50 TUE), na którą wkroczyło Zjednoczone Królestwo, rozpoczyna się notyfikacją demokratycznie podjętej decyzji państwa o wystąpieniu z UE. Mimo poważnych turbulencji wokół brexitu, nikt nie kwestionuje demokratycznego charakteru Zjednoczonego Królestwa, czy podejmowanych tam decyzji. Inaczej będzie sprawa wyglądała w przypadku państwa niepraworządnego - czy decyzja podjęta przez reżim niepraworządny w sprawie wystąpienia z Unii może być dla Unii Europejskiej miarodajna? Czy państwo autorytarne może być wiarygodnym partnerem w negocjowaniu warunków wystąpienia i przyszłego kształtu stosunków z Unią Europejską? Wydaje się, że gdyby „sytuacja dojrzała” do pozbycia się niepraworządnego państwa z grona państw członkowskich UE, to zostanie ono po prostu z Unii wyrzucone. Byłaby to dla Unii sytuacja znacznie „łatwiejsza”, bowiem samodzielnie określałaby warunki pozbycia się takiego państwa, natomiast konsekwencje finansowe, zważywszy, że wchodzące w grę państwa są tzw. beneficjentami, byłyby umiarkowane (Barcz, 2019, s. 22-23).

\section{Podsumowania i wnioski}

4.1. Uogólniając badaną problematykę relacji politycznych państwa z Kościołem katolickim nasuwają się dwa następujące wnioski:

- Idee transformacji miały świecki charakter. Konstytucje słusznie promowały rozdzielenie kościołów od państwa, nawet jeśli w założeniu ten rozdział miał mieć przyjazny charakter. Z czasem kościoły, zwłaszcza dominujące, zapragnęły więcej przywilejów i władzy, a zarazem dla coraz większej liczby ludzi biednych, opuszczonych,

16 „Gazeta Wyborcza” z dn. 17 stycznia 2020 r. 
wykluczonych, pokrzywdzonych religia i kościół stały się głównym źródłem wsparcia duchowego i moralnego. Jednak polityczne centrum przez lata nie dostrzegało tych potrzeb, pozostawiając religijność fundamentalistom i wojującym księżom. Warto więc dziś szukać ludzi przyjaźnie nastawionych do demokracji i wolności wśród wierzących i umiarkowanych księży. Tworzyć z kościołami sojusze, które będą służyć lokalnym społecznościom.

- Postawa historyczna kościołów często prowadziła do wojen, masowych mordów czy naruszeń praw mniejszości. Ale zarazem zdecydowana większość ludzi, którzy ryzykowali życie, by nieść pomoc ofiarom masowych zbrodni, którzy wyciągali ludzi z niewoli i z głodu, którzy jeżdżą na tereny objęte wojnami z pomocą humanitarną, robi to $\mathrm{w}$ imię swej wiary religijnej, z poczucia obowiązku wobec Boga, jakkolwiek go rozumieją, oraz niespokrewnionych z nimi cierpiących ludzi. Filozofia dobrego Samarytanina kierowała tymi, którzy pomagali zbiegłym niewolnikom z południa USA oraz Żydom w czasie Holocaustu i którzy nieśli pomoc w Biafrze, Rwandzie czy południowym Sudanie.

4.2. Refleksja o toksycznym patriotyzmie:

- Patriotyzm jest materią bardziej skomplikowaną niżby można było sądzić. Zaś definicja tego pojęcia znacznie odbiega od znanego stereotypu: patriotyzm to miłość do ojczyzny. Jak zatem określić granice patriotyzmu, gdzie go umieścić? Wydaje się, że leży on pomiędzy internacjonalizmem a nacjonalizmem, którą łatwo można przekroczyć $\mathrm{w}$ obydwie strony. Internacjonalizm jest mniej niebezpieczny i jest szkodzeniem przede wszystkim sobie, bo prowadzi do wyobcowania. Wybór nacjonalizmu mimo deklarowanej wielkiej miłości, wierności do własnego kraju, narodu, grupy społecznej szkodzi wszystkim, a dla odstępców staje się niebezpieczny.

4.3. Nienawiść powodująca anomię, która ma różne oblicza w artykule prezentujemy trzy uogólnienia:

- Nienawiść może mieć wymiar jednostkowy lub społeczny (kiedy jest skierowana przeciwko grupom społecznym, wyodrębnionym np. ze względu na kryteria: rasowe, etniczne, wyznaniowe, ideologiczne lub inne. Osoba (grupa społeczna) nienawidząca z zasady uznaje, że unicestwiając obiekt nienawiści wypełnia szczególną wizję i nie narusza przy tym żadnych wartości i norm moralnych.

- Nienawiść ma źródło w skrajnym egoizmie lub resentymencie, skrajnym partykularyzmie grupowym, które nie pozwalają dostrzec w in- 
nej osobie lub grupie społecznej podmiotów stosunków społecznych i wartości moralnej.

- Nienawiść jest dążeniem do własnej afirmacji za wszelką cenę, co nie pozwala na akceptowanie innych poglądów i ludzi. Źródłem nienawiści mogą być zawiść, pycha, przekonania polityczne, odmienności rasowe, etniczne, narodowościowe, seksualne oraz konflikty trudne do przewidzenia. Człowiek kierowany nienawiścią jest przekonany, że ma prawo do poniżania i postponowania obiektu swych uczuć.

4.4. W kwestiach ładu kulturowego w Polsce oraz zagrożenia integracji z Unią Europejską co generuje dystopię sformułowano trzy ważne wnioski:

- Zagrożenie integracji z Unią Europejską wynika z nieprzystawalności aksjologicznej środowiska PiS do współczesnej tożsamości europejskiej, która dla nich jest rażąca i obca kulturowo. Politycy partii rządzącej muszą na spotkaniach unijnych czuć się wyobcowani i nierozumiani przez co od lat niechybnie narasta ich zwyczajny, ludzki resentyment. Nic dziwnego, że trudno im zrozumieć zarzuty Europy wobec zmian w polskim wymiarze sprawiedliwości, skoro operują zupełnie innymi zestawami pojęć i hierarchiami wartości.

- Wniosek drugi jest konkretny i sformułował go zarówno Witold Waszczykowski, jeszcze gdy kierował MSZ, jak i - nawet czytelniej PiS-owski ambasador w Berlinie Andrzej Przyłębski w kilkukrotnie powtarzanych wypowiedziach dla różnych mediów niemieckich; rząd PiS nie chce polexitu, ale nie chce także być w takiej Unii jak obecna. Chce głębokiej reformy UE, a jej kierunek szedłby ewidentnie pod prąd aktualnych tendencji. Waszczykowski sugerował powrót do strefy wolnego handlu lub unii celnej. Przyłębski skupia się na usunięciu z agendy Unii wszystkiego, co kulturowo razi polskiego konserwatystę. Nie chcą też wspólnej waluty euro (Piwnicki, 2016, s. 91-106).

- Co jednak, jeśli Unia będzie, a wszystko na to wskazuje, i pójdzie w kierunku pogłębiania integracji? Tutaj pojawia się wniosek trzeci. PiS chce otworzyć sobie drogę do politycznej opcji, jaką jest polexit. Chciałby, aby taka możliwość realnie znalazła się na stole i poszerzyła pole manewru tej partii. A wypowiedzi polityków przygotowują polskich wyborców i obywateli do zmiany stanowiska w sprawie polexitu oraz otwarcia ich emocji i umysłów na taką ewentualność w perspektywie kolejnej kadencji rządów PiS (lub dwóch kadencji), po 2019 roku.

4.5. O niepraworządności w Unii Europejskiej zaprezentowano dwa wnioski: 
- Państwa członkowskie, w których dochodzi do systematycznych naruszeń praworządności (Węgry i Polska) nie są wcale osamotnione. Rządzące w nich formacje „wpisują się” w szersze zjawiska polityczne, charakteryzujące się populizmem, nacjonalizmem, skrywanym antysemityzmem, odrzucające model demokratycznych rządów prawa i gospodarki rynkowej.

- Wspólnym mianownikiem wymienionych wyżej państw jest eurosceptycyzm, odrzucający ścisłe współdziałanie państw w ramach procesu integracji europejskiej. Jak, wspomniano wyżej, dotychczas niekwestionowanym założeniem konstrukcji europejskiej było budowanie wspólnoty państw demokratycznych.

\section{Bibliografia}

Beniuszys P. (2019), Bronimy się przed Polexitem, „Gazeta Wyborcza” z dn. 3.01.

Barcz J. (2019), Unia Europejska wobec nieprawidłowości, „Res Humania Humanizm Racjonalizm Kultura Świecka" 1/158.

Dostatni T. (2017), Partie ewangelii nie głosza, „Gazeta Wyborcza” z dn. 6.04.

Durkheim E. (1961), Typy samobójstw, w: J. Szacki, Durkheim, Warszawa.

Głażewski M. (2010), Dystopia albo ontologia Zto-bytu, „Przegląd Pedagogiczny”.

Konstytucja Rzeczypospolitej Polskiej z dnia 2 kwietnia 1997.

Kopeć J. (2018), Stany Zjednoczone Europy, „Gazeta Wyborcza” z dn. 5-6.05.

Korzeniowski K. (2002), Utrata i poszukiwanie społeczno-politycznego sensu. Anomia i paranoja polityczna, w: Postawy psychologii politycznej, pod red. K. Skarżyńskiej, Poznań.

Krasowski R. (2016), Czas Kaczyńskiego. Polityka jako wieczny konflikt, Warszawa.

Kula W. (1983), Historia, zacofanie, rozwój, Warszawa.

Lewandowski J. (2018), Unia Europejska jest jak zdrowie..., „Gazeta Wyborcza” $\mathrm{z}$ dn. 7.12 .

MacIver R. (1950), The ramparts guard, New York.

Majmurek J. (2017), To młodzi urządza naprawdę świecki kraj, „Gazeta Wyborcza” $\mathrm{z}$ dn. 8.03 .

Małowist M. (1973), Wschód a Zachód Europy w XIII-XVI wieku. Konfrontacja struktur spoleczno-gospodarczych, Warszawa.

Merton R. K. (1982), Teoria socjologiczna i struktura spoleczna, Warszawa.

Norwid C. K. (1984), Pisma wierszem i proza, Warszawa.

Olszewski M. (2018), Kraj na klamstwie zbudowany Polacy kochaja czuć się urażeni, „Gazeta Wyborcza” z dn. 25-26.08.

Orwell G. (1988), Rok 1984, Warszawa. 
Piwnicki G. (2017), Syndrom integracji w stosunkach Polski z Unia Europejska po roku 2015, „Środkowoeuropejskie Studia Polityczne”, nr 3.

Piwnicki G. (2016), Dylematy wprowadzenia euro w Polsce przez pryzmat polityczny i gospodarczy, „Przegląd Polityczny”, nr 1.

Piwnicki G. (2017), Relacje państwo - kościół na przełomie XX i XXI wieku. Przypadek Polski, „Cywilizacja i Polityka”, nr 15.

Podstawy psychologii politycznej (2002), red. K. Skarżyńska, Poznań.

Polskie encyklopedie humanistyczne.

Rupnik J. (2018), Wywiad dla Newsweeka, Coraz mniej Unii, przeprowadził M. Nowicki, „Newsweek” z dn. 15-21.10.2018.

Sikorski Cz. (2016), Toksyczny patriotyzm PiS, „Przegląd” z dn. 21-27 listopada 2016.

Skarga B. (2009), Przeciw nienawiści, „Gazeta Wyborcza” z dn. 19-20 września 2009.

Skarżyński S. (2018), Czy królewna Warszawa rzuci księcia Europę, „Gazeta Wyborcza" z dn. 12-13.05.2018.

Sosnowska A. (2004), Zrozumieć zacofanie. Spór historyków o Europę Wschodnia (1947-1994), Trio, Warszawa.

Starnowski M., Wielgosz P. (2007), Przedmowa do: I. Wallerstein, Analiza systemów - światów, Warszawa, s. I-XXXIV.

Sztompka P. (2003), Socjologia, Kraków.

Utopie, antyutopie, dystopie (2017), pod red. J. Barwicka-Tylek, P. Eckhard, M. Guzy, Prace KNHD 2017, Kraków.

Wallerstein I. (2007), Analiza systemów światów, Warszawa.

Wężyk K. (2017), rozmawia z Georiem Friedmanem, Polacy robią swoje, Unia może Wam skoczyć, „Gazeta Wyborcza” z dn. 25.02.

Wilgocki M. (2017), Trudno nie mieć skojarzeń z faszyzmem, rozmowa z o. Tomaszem Dostatnim z dn. 4.04.

Wróbel S. (2018), Idea Europy, „Przegląd Polityczny”, nr 151/152.

Wywiad dla Polski z Timotym Synderem przeprowadzony przez T. Targańskiego, $\mathrm{z}$ dn. 2.08.2019.

\section{Anomie as a cultural state of Polish society in the early modern period - the underlying cause of the dystopia of integration with the European Union}

\section{Summary}

The article analyzes the issue of integration with the European Union viewed through the prism of historical factors that have played a significant role in Poland being part of central Europe. This has been assumed to stem from the economic divi- 
sion into Western (capitalist) and Eastern (agricultural) Europe in the 16th century, which implied the cultural disparity of those areas and that has lasted until the present in the central and Eastern regions. This division was created by feudal relations in the East and capitalist relations in the West, until the second half of the 19th century. The absence of the modern state with its administrative systems, strong government and army, bourgeoisie and new religious movements, such as Protestantism, all contributed to the development of anomie and dystopia in Poland. The second aspect of this academic analysis is the abandonment of integration with the European Union after 2015. It resulted in the possibility of Poland being ousted from the Western European center of civilization. The prospect of Poland becoming a periphery of Europe is a peculiar anomie and dystopia for the state and society.

Key words: anomie, dystopia, European Union, integration, reintegration 